\title{
POTENTIAL GROWTH, MISALLOCATION, AND INSTITUTIONAL OBSTACLES: FIRM-LEVEL EVIDENCE
}

Miguel León-Ledesma

NO. 480

April 2016
ADB ECONOMICS WORKING PAPER SERIES 
ADB Economics Working Paper Series

\section{Potential Growth, Misallocation, and Institutional Obstacles: Firm-Level Evidence}

Miguel León-Ledesma

No. 480 | April 2016
Miguel León-Ledesma (M.A.Leon-Ledesma@kent.ac .uk) is a professor of the School of Economics and a director of the Macroeconomics, Growth and History Centre at the University of Kent.

This work has been prepared as a background paper for the Asian Development Outlook 2016 theme chapter on Asia's Potential Growth. The author is grateful to Dimitris Christopoulos, Jesus Felipe, Kozo Kiyota, Shang-Jin Wei, and participants in the ADO-ADR Workshop in Seoul in November 2015, for very useful comments and discussions. The author also acknowledges Alessandro Cusimano and Daniel Roland for superb research assistance. 
Asian Development Bank

6 ADB Avenue, Mandaluyong City

1550 Metro Manila, Philippines

www.adb.org

(C) 2016 by Asian Development Bank

April 2016

ISSN 2313-6537 (Print), 2313-6545 (e-ISSN)

Publication Stock No. WPS167972-2

The views expressed in this paper are those of the author and do not necessarily reflect the views and policies of the Asian Development Bank (ADB) or its Board of Governors or the governments they represent.

ADB does not guarantee the accuracy of the data included in this publication and accepts no responsibility for any consequence of their use.

By making any designation of or reference to a particular territory or geographic area, or by using the term "country" in this document, $A D B$ does not intend to make any judgments as to the legal or other status of any territory or area.

Note: In this publication, "\$” refers to US dollars.

The ADB Economics Working Paper Series is a forum for stimulating discussion and eliciting feedback on ongoing and recently completed research and policy studies undertaken by the Asian Development Bank (ADB) staff, consultants, or resource persons. The series deals with key economic and development problems, particularly those facing the Asia and Pacific region; as well as conceptual, analytical, or methodological issues relating to project/program economic analysis, and statistical data and measurement. The series aims to enhance the knowledge on Asia's development and policy challenges; strengthen analytical rigor and quality of ADB's country partnership strategies, and its subregional and country operations; and improve the quality and availability of statistical data and development indicators for monitoring development effectiveness.

The ADB Economics Working Paper Series is a quick-disseminating, informal publication whose titles could subsequently be revised for publication as articles in professional journals or chapters in books. The series is maintained by the Economic Research and Regional Cooperation Department. 


\section{CONTENTS}

TABLES AND FIGURES

ABSTRACT $v$

$\begin{array}{ll}\text { I. INTRODUCTION } & 1\end{array}$

II. MISALLOCATION: CONCEPTS AND MEASUREMENT 2

A. Key Concepts 2

B. Misallocation and Wedges 3

C. Measuring Misallocation 6

D. What is the Source of Distortions? Misallocation Theories 7

III. METHODOLOGY AND FIRM LEVEL DATA 9

A. Methodology 9

B. The Data 10

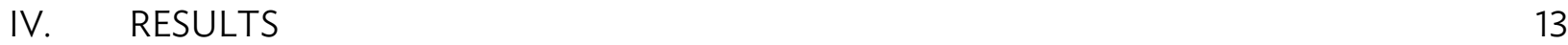

A. Measures of Misallocation 13

B. Obstacles and Misallocation: Country-Level Evidence 14

C. Obstacles and Misallocation: Firm-Level Evidence 16

D. Firm-Level Results for Asian Countries 20

E. Splitting Countries by Levels of Development 22

$\begin{array}{llr}\text { V. CONCLUSIONS } & 24\end{array}$

$\begin{array}{lr}\text { REFERENCES } & 27\end{array}$ 


\section{TABLES AND FIGURES}

\section{TABLES}

$1 \quad$ Number of Firms and Distribution by Size 11

$2 \quad$ List of Institutional Obstacles 12

3 Summary Statistics of Misallocation Measures 13

$4 \quad$ Correlation between Misallocation Measures 13

5 Cross Country Regression: Measures of Misallocation on Obstacles 15

$6 \quad$ Firm-Level Regression of log MRPK on Obstacles 17

$7 \quad$ Firm-Level Regression of $\log \left(\tau_{y}\right)$ on Obstacles 18

$8 \quad$ Firm-Level Regression of $\log \left(\tau_{k}\right)$ on Obstacles 19

9 Prevalence of Obstacles in Asian Countries 20

\section{FIGURES}

1 Distribution of Measures of Misallocation 13

2 Regression Coefficients for $\tau_{y}$, No Country Dummies $\quad 21$

3 Regression Coefficients for $\tau_{y}$, With Country Dummies 21

$4 \quad$ Regression Coefficients for $\tau_{k}$, No Country Dummies $\quad 21$

$5 \quad$ Regression Coefficients for $\tau_{k}$, With Country Dummies 22

6 Regression Coefficients for $\tau_{y}$, No Country Dummies 23

$7 \quad$ Regression Coefficients for $\tau_{y}$, With Country Dummies 23

$8 \quad$ Regression Coefficients for $\tau_{k}$, No Country Dummies 23

9 Regression Coefficients for $\tau_{k}$, With Country Dummies 24 


\begin{abstract}
One of the key determinants of potential growth are productivity gains. Total factor productivity (TFP) differences are the main determinant of per capita income differences between countries. A key factor to understand TFP is misallocation: the aggregate productivity loss from microeconomic distortions that prevent factors of production from being allocated to their optimal use. If misallocation is a key determinant of TFP differences, then reallocation of factors of production is a key driver of productivity gains. Since distortions preventing misallocation can be driven by institutional obstacles, then policies focused on the removal of these obstacles will affect potential growth. In this paper, we use a firm-level database for 62 developing countries to analyze which are the most important institutional obstacles driving misallocation. Our results highlight the importance of trade regulations, the functioning of courts, and access to finance as key determinants of misallocation within countries. Political instability, labor regulations, and access to infrastructure, appear as relevant obstacles explaining misallocation between countries.
\end{abstract}

Keywords: firm level, misallocation, potential growth, productivity

JEL codes: $\mathrm{O} 40,043,047$ 


\section{INTRODUCTION}

In the long run, the potential rate of growth of an economy is driven by and large by productivity or efficiency gains. The dispersion in per capita incomes between countries in the world economy can be explained mostly by the dispersion of total factor productivity (TFP), see Caselli (2005). By implication, analyzing productivity growth should be one of the key elements of any study trying to address potential growth. But what determines differences in TFPs? It is difficult to argue that the remarkable persistence of TFP differences between countries is simply due to slow technology diffusion. Driven by this observation, recent literature has shifted the focus of analysis to the role of misallocation. Misallocation implies that, given aggregate endowments of capital and labor, and given firms' levels of TFP, aggregate TFP could be higher if factors are efficiently reallocated between firms. If misallocation plays an important role in driving per capita income differences between countries, then reallocation of resources between production units plays a crucial role in explaining productivity growth and potential growth.

In this background paper, we analyze the role of institutional obstacles to firms' activities in driving misallocation across countries in the world. Within this context, we then analyze where several Asian economies stand in terms of institutional obstacles. We consider a wide range of obstacles ranging from infrastructure, taxation, corruption, and labor and capital market distortions. We do so by using firm-level data for 62 countries from the World Bank Enterprise Surveys. We derive overall measures of misallocation and distortions that affect firm size and factor markets. We then regress measures of misallocation on firms' declared institutional obstacles. Thus, we ask where the most important distortions that prevent efficient factor allocation originate from. This is important from the viewpoint of academic debates on the key sources of misallocation.

The relevance of understanding the role of obstacles is evident also from a policy perspective. The removal or improvement of certain distortions is likely to trigger an efficient reallocation of resources between firms that leads to an increase in aggregate productivity even without changes in aggregate factor inputs or firm-level technology. In the transition toward the new, improved, allocation the rate of potential growth increases. This implies that the potential rate of growth is not independent from policies. Countries that are far away from the world technology frontier have a greater growth potential. But this potential can only be realized if particular policies are in place that allow for the reallocation of economic activity at the micro level. Few people would doubt that, had we estimated potential growth in the People's Republic of China (PRC) in 1975 and in 1995, they would have differed dramatically. Few people would also doubt the role that economic reforms had in this dramatic increase in growth potential. Changes in firm-level misallocation are one, though not the only, ${ }^{1}$ important factor that has driven this transformation.

Our main findings are as follows. There is a large degree of misallocation of resources in our sample of developing countries, implying very large potential growth gains from reallocation. Misallocation is statistically and economically significantly related to institutional obstacles. Trade regulations, the functioning of courts, and access to finance, appear to be key determinants of misallocation within countries. Political instability, labor regulations, and access to infrastructure, are the main determinants of misallocation between countries. We also highlight some differences in the determinants of misallocation for Asian countries, and split the sample between the richest and poorest half.

\footnotetext{
Other important effects of policy reforms at the micro level relate to firm dynamics, i.e., reallocation of resources through
} firm entry and exit. 
Our paper is related to a growing body of theoretical and empirical literature that has emerged in the past decade. The role of misallocation has been emphasized since the seminar work of Hopenhayn and Rogerson (1993) and the contributions of Banerjee and Duflo (2005); Restuccia and Rogerson (2008); Guner, Ventura, and Xu (2008); and Bartelsman, Haltiwanger, and Scarpetta (2013) to name a few. Hsieh and Klenow (2009) develop a method to measure how distortions at the micro level imply aggregate TFP losses and use it to quantify TFP loses in the PRC and India relative to the United States (US). Their findings show that, had the PRC and India had similar levels of misallocation to the US, their TFP could be between $30 \%$ and $60 \%$ higher, respectively. Kalemli-Ozcan and Sorensen (2012) use a similar approach to ours by investigating the role of access to finance for misallocation in African countries. Their study is limited to the role of financial access in Africa, whereas ours considers a wider range of countries and measures of obstacles. Our approach also uses a wider range of measures of misallocation and separates factor market distortions from distortions that affect firm size.

In what follows, the paper will first discuss the concept of misallocation, including theoretical aspects and measurement issues. We then present and discuss the data and methodology, followed by the key results. We pay special attention to how Asian economies in our sample fare in comparative terms. In the final section we conclude.

\section{MISALLOCATION: CONCEPTS AND MEASUREMENT}

As mentioned in the introduction, misallocation conceptualizes the view that lack of development is not the consequence of lack of resources (capital, labor, and knowledge) but a failure to allocate these resources to their most efficient use. Misallocation is a persistent phenomenon (see Banerjee and Moll 2010) which suggests it is caused by certain distortions related to institutional features of the economy such as regulation, market structures, and (lack of) reforms. It is precisely changes to these that can trigger growth takeoffs where the potential rate of growth changes in transition toward a new steady state as a consequence of TFP gains. We first discuss the concept of misallocation using a simple example and the model of Hsieh and Klenow (2009). We then discuss some theoretical models that rationalize misallocation and, finally, we discuss some key measures of misallocation.

\section{A. Key Concepts}

Perhaps the simplest way to think about misallocation can be explained using an example with only two firms taken from Jones (2011). Consider an economy where there are only two firms: one that produces clothes and another one that produces laptops. The technology of production for each firm is such that only one worker is required to produce one unit:

$$
Y_{\text {clothes }}=L_{\text {clothes }}, Y_{\text {laptops }}=L_{\text {laptops }}
$$

The resource constraint in the economy is such that aggregate labor $(\bar{L})$ must be allocated to either firm such that: $\bar{L}=L_{\text {clothes }}+L_{\text {laptops }}$. Finally, let us assume that clothes and laptops are combined to produce a "final good" $Y$ (which can be seen as a utility-based aggregation) using a CobbDouglas type technology:

$$
Y=Y_{\text {clothes }}^{1 / 2} Y_{\text {laptops }}^{1 / 2}
$$


Now define $x=\frac{L_{\text {clothes }}}{\bar{L}}$ as the share of workers allocated to the clothes-producing sector. Thus $(1-x)$ is the share allocated to the laptops sector. Given the allocation of labor between sectors, aggregating we obtain final output as a function of $x$ :

$$
Y=A(x) \bar{L}
$$

where

$$
A(x)=\sqrt{x(1-x)}
$$

As the setup is such that both firms are symmetric, the optimal allocation of labor between the two firms leads to $x^{*}=0.5$, where $x^{*}$ is the optimal $x$. This is the value of $x$ that maximizes $A(x)$, which is the aggregate TFP in the economy. Now, suppose that $x$ differs from 0.5 . In this case, aggregate TFP will be lower not because firms' productivities have changed, but because labor is misallocated. Since both firms are equally productive, they should be allocated equal amounts of labor. If one firm was more productive, then it should be allocated more labor in proportion to its relative productivity. But what is important to note in this example is that, with the same amount of inputs $(L)$ and firms' productive technology, aggregate TFP can increase if labor is reallocated such that $x=0.5{ }^{2}$

The literature on how misallocation explains per capita income differences between countries and how reallocation thus affects income growth has evolved greatly in the past 10 years. The increased availability of comparable firm-level data has made quantitative analyses of misallocation within sectors possible (see Foster, Haltiwanger, and Syverson 2008; and Hsieh and Klenow 2009). However, and in order to understand the quantitative implications of misallocation, we require theory models where misallocation can arise. These theory models share two key characteristics that are jointly essential to create misallocation: a) firm heterogeneity; b) distortions. The former is necessary since, if all firms were exactly the same, a random allocation of resources across them would deliver the same aggregate productivity as a different allocation. ${ }^{3}$ The latter is necessary since distortions prevent firms from hiring factors of production (i.e., acquiring a size) according to their level of productivity. A popular model to measure misallocation due to distortions is Hsieh and Klenow (2009), which we briefly describe below.

\section{B. Misallocation and Wedges}

In Hsieh and Klenow (2009) (HK hereafter) misallocation arises as a consequence of distortions or wedges that affect firms in a heterogeneous manner. These wedges, which are akin to taxes, prevent heterogeneous firms from achieving their optimal size, thereby leading to aggregate TFP losses. The HK model is also important to obtain and understand measures of misallocation.

In the original HK model, there are $S$ industries and $M$ firms within each of the $S$ industries. For simplicity, we will assume that the economy only has one industry, but the key arguments are

2 When comparing countries in terms of their degrees of misallocation, we are implicitly assuming that preferences are the same and thus they do not affect the relative allocations between countries. This, of course, may not be the case in reality, but it is unlikely to explain the large differences observed in the data.

3 In the example above, the two industries are heterogeneous in the sense that they are not perfect substitutes as intermediate inputs in the final output production function. 
preserved. ${ }^{4}$ The total final output in the economy $(Y)$, is a Dixit-Stiglitz aggregator of the output produced by each firm $\left(Y_{i}\right)$ :

$$
Y=\left(\sum_{i=1}^{M} Y_{i}^{\frac{\sigma-1}{\sigma}}\right)^{\frac{\sigma}{\sigma-1}}
$$

where $\sigma$ is the elasticity of substitution between varieties. Each firm's production function is given by a Cobb-Douglas aggregator of capital $(K)$ and labor $(L)$ with individual firm's TFP given by $A_{i}:{ }^{5}$

$$
Y_{i}=A_{i} K_{i}^{\alpha} L_{i}^{1-\alpha}
$$

There are two distortions or "wedges" affecting firms. One that affects output or firm size $\left(\tau_{y, i}\right)$, and another that affects relative factor inputs $\left(\tau_{k, i}\right)$. Since it is not possible to separately identify wedges that affect capital and labor, we choose to impose the wedge on capital, but this is to be interpreted as a distortion that affects the relative price of capital and labor. As these wedges are firm specific, they will not affect all firms the same way, thus generating differences in capital-labor ratios between firms. With these wedges, the problem of the firm is to choose $K$ and $L$ to maximize profits $\left(\pi_{i}\right)$ :

$$
\pi_{i}=\max _{K, L}\left[\left(1-\tau_{y, i}\right) P_{i} Y_{i}-w L_{i}-\left(1+\tau_{k, i}\right) R K_{i}\right]
$$

where $P$ is the price of the final good, $w$ is the wage rate, and $R$ is the rental price of capital. Note that, since factor markets are competitive, all firms face the same factor prices.

Using the first order conditions for capital and labor, substituting them in the production function and finding the optimal price for each variety yields the standard result that price is a markup over marginal costs: $P_{i}=\frac{\sigma}{1-\sigma}\left(\frac{R}{\alpha}\right)^{\alpha}\left(\frac{w}{1-\alpha}\right)^{1-\alpha} \frac{\left(1+\tau_{k, i}\right)^{\alpha}}{A_{i}\left(1-\tau_{y, i}\right)}$. Note that, with this pricing rule, the quantities of labor demanded and the quantity of output produced by each firm are proportional to their individual TFPs and the idiosyncratic distortions or wedges they face. In the absence of distortions, firms' relative shares of output and labor would just be a function of $A_{i}$. The capital-labor ratio is given by:

$$
\frac{K_{i}}{L_{i}}=\frac{\alpha}{1-\alpha} \frac{w}{R} \frac{1}{1+\tau_{k, i}}
$$

which implies that the factor market idiosyncratic distortion prevents firms from equalizing their capital-labor ratios.

The marginal revenue product of capital is given by $M R P K_{i}=P_{i} M P K_{i}$. Given the definition of MPK, we obtain:

4 In the empirical analysis, we also assume the economy only has one sector as the dataset contains incomplete information about the sectors to which firms belong, and for many countries and sectors the number of firms is very limited. This will tend to inflate our distortion measures as discussed below.

5 The Cobb-Douglas assumption is not innocuous. If the elasticity of substitution between capital and labor differs from one, then the dispersion of the marginal product of capital and hence the gains from reallocation can change substantially. The more substitutes capital and labor are, the more technologically similar they are and the less important will relative factor market distortions be. Recent evidence suggests that this elasticity significantly differs from unity (see LeónLedesma, McAdam, and Willman 2010, 2015). 


$$
M R P K_{i}=\alpha \frac{\sigma-1}{\sigma} \frac{P_{i} Y_{i}}{K_{i}}=R \frac{1+\tau_{k, i}}{1-\tau_{y, i}}
$$

Likewise, total factor productivity revenue, is defined as $T F P R_{i}=P_{i} A_{i}$, which, using the definition of prices yields:

$$
\operatorname{TFPR}_{i}=\frac{\sigma}{1-\sigma}\left(\frac{R}{\alpha}\right)^{\alpha}\left(\frac{w}{1-\alpha}\right)^{1-\alpha} \frac{\left(1+\tau_{k, i}\right)^{\alpha}}{\left(1-\tau_{y, i}\right)}
$$

From (9) and (10) above, it is clear that, in the absence of distortions, marginal revenue products of capital and TFPR would equalize across firms. If a firm has a relatively high $A_{i}$, it will attract more capital and labor, until its price falls such that its $T F P R_{i}$ equalizes that of lower-productivity firms. Thus, as discussed below, the dispersion of MRPKs and/or TFPRs is a measure of idiosyncratic distortions affecting firm sizes. (8) we get:

It is also possible to obtain independent measures of size and factor market distortions. From

$$
1+\tau_{k, i}=\frac{\alpha}{1-\alpha} \frac{w L_{i}}{R K_{i}}
$$

and combining this with (9) we find:

$$
1-\tau_{y, i}=\frac{\sigma}{1-\sigma} \frac{w L_{i}}{(1-\alpha) P_{i} Y_{i}}
$$

Thus, the factor market distortion measures the firm's relative cost share of labor and capital relative to that for the economy represented by $\alpha /(1-\alpha)$. The size distortion measures the cost share of labor for the firm relative to that for the economy given by $(1-\alpha)$.

Note that what we observe in the data are the $M R P K_{i}$ and $T F P R_{i}$ and not $M P K_{i}$ and $T F P_{i}$ for every firm as we do not observe individual firm prices. This is why HK make an assumption about market structure to infer prices as a function of firm productivity and distortions.

Aggregate TFP is defined as aggregate TFPR over aggregate prices. Using the final product aggregator, we obtain:

$$
T F P=\frac{T F P R}{P}=\left[\sum_{i=1}^{M}\left(A_{i} \frac{\overline{T F P R}}{T F P R_{i}}\right)^{\sigma-1}\right]^{\frac{1}{\sigma-1}}
$$

where $\overline{T F P} \bar{R}$ is the weighted average of TFPR for all firms in the economy. If all firms were the same, i.e., with no heterogeneity, the ratio in the brackets would disappear. At this point, aggregate TFP is maximized. That is, aggregate TFP is maximized when there is no dispersion in TFPR $R_{i}$ This gives us the "optimal level of TFP" when there are no distortions:

$$
T F P^{*}=\left[\sum_{i=1}^{M} A_{i}^{\sigma-1}\right]^{\frac{1}{\sigma-1}}
$$


Using this result, we can then calculate the productivity loss due to idiosyncratic distortions using the ratio between observed TFP given by (13) and optimal TFP given by (14): $\frac{T F P^{*}}{T F P}-1$. Calibrating parameters $\sigma, \alpha$, and $R$, and with the observed firm-level data for the rest of the variables, it is possible then to pin down the distortions and the TFP loss from the data. HK find that, if the distribution of $T F P R_{i}$ for Chinese and Indian firms was similar to that of the US, Chinese aggregate TFP could increase by $30 \%-50 \%$, and Indian aggregate TFP by $40 \%-60 \%$.

It is worth noting then that these potentially large aggregate TFP gains could theoretically be achieved without any change in factor inputs or firm-level technology. What is important is that certain distortions prevent firms from achieving their optimal size and thus the joint distribution of $T F P_{i}$ and firm sizes is distorted.

\section{Measuring Misallocation}

From the discussion of the HK model, it is easy to understand common measures of misallocation used in the literature. We discuss several of these relevant measures below. The first three derive directly from the HK model, and the last two are less structural as they do not require the parameterization of certain model elasticities.

(i) From Equation (9) above, the MRPK would equalize between firms if distortions were not heterogeneous. Thus, the standard deviation of the (log of) MRPK would in itself be a measure of both size and factor market distortions. Since $\log \left(M R P K_{i}\right) \propto \log \frac{P_{i} Y_{i}}{K_{i}}$, then we can measure misallocation as: $\operatorname{STDEV}\left(\log M R P K_{i}\right)=\operatorname{STDEV}\left(\log \frac{P_{i} Y_{i}}{K_{i}}\right)$. Note that an alternative measure of the same distortion (scaled up to the capital share) would apply by calculating the dispersion of the TFPR as given in Equation (10). As discussed above, with no heterogeneous distortions TFPR should equalize between firms. Note that these measures depend on certain assumptions such as the shape of the production function and market structure.

(ii) Similarly, from (11), a measure of misallocation arising from factor market distortions would correspond to the dispersion of $\tau_{k}$. As $\log \left(1+\tau_{k, i}\right) \propto \log \frac{w L_{i}}{R K_{i}}$, then $\operatorname{STDEV}\left(\tau_{k, i}\right)=$ $\operatorname{STDEV}\left(\log \frac{w L_{i}}{R K_{i}}\right)$.

(iii) From Equation (12), and just like for the factor market distortion, we can obtain a measure of size distortions as $\operatorname{STDEV}\left(\tau_{y, i}\right)=\operatorname{STDEV}\left(\log \frac{w L_{i}}{R K_{i}}\right)$.

(iv) Two less structural, but related, measures arise from the so-called Olley-Pakes covariance term discussed in Bartelsman, Haltiwanger, and Scarpetta (2013) and originally due to Olley and Pakes (1996). These measure the covariance between an index of productivity and a measure of firm size. A country (or industry) productivity level $(Q)$ is the weighted average of firm-level productivity. This can be decomposed in the following way:

$$
Q=\sum_{i} q_{i} \omega_{i}=\bar{q}+\underbrace{\sum_{i}\left(q_{i}-\bar{q}\right)\left(\omega_{i}-\bar{\omega}\right)}_{\Omega},
$$

where $q_{i}$ is the productivity index for firm $i, \omega_{i}$ is the share of economic activity of the firm (the weight) and a bar over a variable denotes its average across firms. Thus, productivity is the sum of the unweighted mean of firm-level productivity and the covariance between productivity and firm size, $\Omega$, 
which is the Olley-Pakes measure. Here, the measure of productivity can be labor productivity or total factor productivity. In the former case, the weights will be employment weights for each firm, and in the latter they are value-added weights. ${ }^{6}$ We will use both measures below.

What this covariance measures is whether highly productive firms have a larger share of economic activity (efficient allocation) or not. If $\Omega=0$, it would mean that aggregate productivity is equivalent to the one we would obtain if firm sizes were randomly allocated across firms, i.e., a case in which resources are misallocated as more productive firms do not attract more resources. A value of, say 0.2 , implies that aggregate productivity is $20 \%$ higher than random. This is, of course, related to the HK model above. Firms with high $A_{i}$ should attract more production inputs until their TFPR $R_{i}$ equalizes that of lower-productivity firms. In the absence of any distortion, all firms would have the same TFPR and aggregate productivity is maximized. Thus, high TFPR firms should be larger, which is precisely what the covariance measure captures.

\section{What is the Source of Distortions? Misallocation Theories}

The quantitative role of reallocation (i.e., falling misallocation) for productivity growth is of a large order of magnitude. For instance, Baily, Hulten, and Campbell (1992) find that $50 \%$ of the growth in productivity for the manufacturing sector in the US was attributable to factor reallocation between firms in the 1970s and 1980s. That is, contracting low-productivity firms and expanding productive firms (see also Foster, Haltiwanger, and Syverson 2008). The common view for emerging markets is that there are a set of institutional features that prevent this efficient reallocation including credit, labor, and land markets imperfections. However, a more difficult task is to understand their quantitative importance. Restuccia and Rogerson (2013), for instance, classify the literature on misallocation broadly into two approaches. The first is the indirect approach, which simply measures the TFP loss arising from misallocation without focusing on specific institutional distortions. This is the approach of the HK model described above. The second is the direct approach, which models the role of specific distortions and quantifies their contribution to misallocation. We focus in this section on the direct approach.

To understand how specific distortions can affect misallocation, it is useful to clarify some concepts. We can use a simple example based on Hopenhayn (1992) and discussed in Restuccia (2013). Suppose firm/establishment output is produced using only labor: $y_{i}=z_{i} l_{i}^{\gamma}$. Establishments differ in terms of their productivity levels $z_{i}$. Labor is supplied inelastically in a competitive market and we normalize the price of the final good to 1 . Standard first order conditions would then dictate that the demand for labor for establishment $i$ is given by: $l_{i}=\left(\frac{z_{i} \gamma}{w}\right)^{\frac{1}{1-\gamma}}$. The relative demand for labor between firms $i$ and $j$ is then $\frac{l_{i}}{l j}=\left(\frac{z_{i}}{z_{j}}\right)^{\frac{1}{1-\gamma}}$. This implies then that higher-productivity firms should be larger as discussed above. Suppose now that there is an idiosyncratic tax on output $\tau_{i}$. In this case, the relative size of two establishments is given by $\frac{l_{i}}{l j}=\left(\frac{\left(1-\tau_{i}\right) z_{i}}{\left(1-\tau_{j}\right) z_{j}}\right)^{\frac{1}{1-\gamma}}$. Thus, the relative size of two establishments is not anymore only dependent on their relative productivity, but on the size of the tax they face. Thus, firms can be larger or smaller now depending on both their productivity and the tax

6 It is possible also to develop dynamic measures of the Olley-Pakes decomposition to highlight the contribution of firmlevel productivity changes, resource reallocation, and entry and exit, for productivity gains. See Melitz and Polanec (forthcoming). This requires panel datasets not available for a wide range of countries. However, where they are available, they are very revealing to understand the limits to potential growth and how its sources can change over time. 
policy. If the tax policy is such that higher taxes are applied to higher-productivity firms, then the relative size of large firms will be lower than optimal leading to misallocation (i.e., a low covariance between size and productivity). This is the argument discussed in Restuccia and Rogerson (2008).

Hopenhayn and Rogerson (1993) is one of the first attempts at rationalizing theoretically the role of misallocation. They focus on the role of rigidities in the labor market in the form of firing and hiring costs in a model of firm entry and exit. When these distortions are present, they affect firm's decisions on whether to enter, to exit, or to continue in the market. They show that these types of distortions would then affect the dispersion in marginal products of labor leading to misallocation. In Hopenhayn and Rogerson (1993), the covariance between distortions and productivity is not important. Restuccia and Rogerson (2008), however, highlight the quantitative role of policies where the distortions faced by firms are correlated with their productivity. They show that, in order for distortions to have a quantitatively important role, they have to be positively correlated with productivity. In a similar spirit, Guner, Ventura, and Xu (2008) analyze the role of "size-dependent policies." That is, policies directed to encourage the growth of smaller firms. An example of this are labor market regulations that start applying only for establishments with more than a certain number of employees. Guner, Ventura, and $\mathrm{Xu}$ (2008) find that policies that reduce the average size of establishments by $20 \%$ lead to reductions in output per establishment of up to $25.6 \%{ }^{7}$

Another potential source of misallocation are trade policies. Distortions in trade policy that affect firms in a heterogeneous fashion reduce competition in certain sectors leading to differences in markups. If markups are different, this will lead to a dispersion in the marginal revenue product of capital and labor and, by implication, in TFPR. Epifani and Gancia (2011) develop a model where heterogeneous exposure to international trade leads to increased markup dispersion and thus misallocation.

Other distortions such as product and factor market regulations affecting firm-entry decisions can have similar effects. For instance, the prevalence of informality in many developing countries with predominantly small and unproductive establishments can lead to large productivity losses. Nevertheless, the use of the informal sector as a way to circumvent these regulations could potentially have opposite effects. Also, competition from the informal sector may affect the markup distribution of firms in the formal sector.

The distortions that have attracted more research, however, relate to capital and credit markets. Midrigan and Xu (2014) report that the dispersion of marginal products of capital is of an order of magnitude several times larger than that for the marginal product of labor and intermediate inputs. Furthermore, this dispersion is very persistent, which implies that capital adjustment costs cannot be the sole source of this dispersion. Since financial systems channel funds from low- to highproductive projects, lack of financial development can hinder TFP. Banerjee and Duflo (2005), for instance, provide evidence on the role of credit constraints and other credit market imperfections for misallocation and hence productivity differences across countries. However, the literature on the relationship between finance and misallocation is far from settled.

7 Another, informal, institution that is size-dependent is corruption. If large firms face larger pressure from politicians to deliver back hand payments, this can also be a source of misallocation. Generally, institutions that are conducive to political interference, graft, and unsecure property rights, are all conducive to misallocation as they will affect more productive firms to a greater extent. 
Moll (2014), in a simple setting where firms face collateral constraints à la Kiyotaki-Moore, shows that, if productivity shocks are persistent, misallocation losses can be large and disappear slowly but are unimportant in steady state. This is because, with persistent shocks, firms can use selffinancing as a form of insurance against incomplete access to credit markets. Banerjee and Moll (2010) argue, however, that misallocation can still exist in steady state at the extensive rather than intensive margin. Buera, Kaboski, and Shin (2011), using a quantitative model with financial frictions, find that they account for around $50 \%$ of TFP gaps between countries. The mechanism is that firms with larger scales of operations are more productive and have more financing needs, thus financial frictions affect them disproportionately. However, Midrigan and Xu (2014), using firm-level data for the Republic of Korea, find that financial frictions have a quantitatively small effect on misallocation. This is consistent with the micro evidence reviewed by Udry (2011), who finds that financial constraints do not play a dominant role in determining misallocation.

Overall, our understanding of the role of institutional constraints on misallocation and hence potential growth gains from reallocation has improved dramatically in the past decade both theoretically and empirically. The sources of misallocation can be many and related to institutional features of the economy, making it difficult to quantitatively isolate separate sources of misallocation. It is also likely that several forms of misallocation can reinforce each other in a way that models with a single friction cannot quantitatively replicate the facts. Also, distortions may directly affect not only the size of firms but their accumulation of productive factors such as human capital or innovation, leading to amplification effects (see Hsieh and Klenow 2012 and Jones 2011). In what follows, we will empirically assess the role of different institutional obstacles for misallocation for developing countries.

\section{METHODOLOGY AND FIRM-LEVEL DATA}

\section{A. Methodology}

Our analysis will be based on a firm-level database for a large number of developing countries. The data and its treatment is explained in the following subsection. The key aim is to understand the role of institutional obstacles related to goods and factor markets and other institutional characteristics in determining misallocation. For this, we first need to create measures of misallocation and then measures of obstacles.

We will use five measures of misallocation consistent with the discussion in Section II.C:

(i) The dispersion in the logarithm of the marginal revenue product of capital (MRPK), which is calculated by assuming a Cobb-Douglas production function. For each country $n$ and firm $i$, we then have that $\log \left(M R P K_{i}^{n}\right) \propto \log \frac{P_{i}^{n} Y_{i}^{n}}{K_{i}^{n}}$. When we calculate the dispersion, we use the standard deviation of $\log \left(M R P K_{i}^{n}\right)$.

(ii) The dispersion of the relative factor cost shares as a measure of factor market distortions as in Equation (9) above.

(iii) The dispersion of the labor cost share as a measure of size distortions as in Equation (10). ${ }^{8}$

(iv) The Olley-Pakes covariance term (OP term) using the log of labor productivity and employment shares.

8 Note we do not need to calibrate $\sigma$ as it drops as a constant and does not affect the results. 
(v) The Olley-Pakes covariance term (OP term) using the log of TFPR and value-added shares. The log of TFPR is calculated as $\log T F P R_{i}^{n}=\log Y_{i}^{n}-\alpha^{n} \log K_{i}^{n}-$ $\left(1-\alpha^{n}\right) \log L_{i}^{n}$. We assume that the output elasticity of capital $\alpha^{n}$ is common for all firms within the same country. This is calculated as one minus the average of the share of wages and salaries in total value added for all the firms in the economy. To prevent the effects of extreme values, we trimmed the upper and lower $10 \%$ of the shares in the sample before calculating the average.

These misallocation measures allow us to compare misallocation between countries. In order to estimate the effects of obstacles, we take two approaches. First, we regress the dispersion and covariance measures for the cross section of countries on measures of obstacles. At the country level, obstacles are measured as the percentage of firms declaring that a specific obstacle is important or severe. Secondly, as in Kalemli-Ozcan and Sorensen (2012) we regress the (log of) MRPK, $\tau_{y}, \tau_{k}$ on obstacles at the firm level. This allows us to understand if institutional obstacles are good predictors of distortions and whether they act as a tax or a subsidy.

\section{B. The Data}

Comparable firm-level data for developing countries covering the whole economy are not available for a sufficiently large number of countries. For this reason, we resort to survey data. Although limited in scope at the country level, survey data are available for a larger number of countries. Thus, we used the World Bank Enterprise Survey data. Specifically, we use the Standardized Data for the 2006-2014 period. This is a stratified survey of firms containing financial and business environment information. The data are purely cross-sectional and come from surveys carried out between 2006 and $2014 .{ }^{9}$ Some countries have been surveyed more than once during this period, so we keep the data for the survey year with more available observations in order not to bias the results by weighting some countries twice. The original data contains 134 surveys and a total of 61,669 firms. However, this number is considerably reduced in the data cleaning process described below. Since we do not have price data for each firm, we are working with revenue-based measures as discussed in the HK model. Data come in local currency units for the survey year. We do not transform them into a common currency since the measures we use are ratios and shares and not absolute values. We calculate the variables of interest as follows:

- $\quad$ Output is measured as Value Added (VA). This is calculated as total annual sales minus the cost of raw materials and intermediate goods.

- The number of workers $(L)$ is the total number of full time employees adjusted for temporary workers.

- $\quad$ Capital $(K)$ is defined as the net book value of machinery, equipment, land, and buildings.

- $\quad$ Total wage bill (WTOT) corresponds to total wages, salaries, and bonuses paid.

- $\quad$ The rental price of capital (RK) is obtained as a residual: (VA - WTOT)/K.

- $\quad$ Labor productivity is VA/L.

We then drop firms for which VA, K, WTOT or RK are negative. We are then left with 45,819 firms. Since we only keep one survey per country by dropping the one with fewer observations, we end up with 62 countries ( 60 countries for some measures). Note also that we dropped any country for which there are less than 100 firms in the sample. Since for many firms not all the required data are

9 The World Bank is currently developing panel datasets for a number of countries and years. However, this is still in its infancy and available for a limited number of countries. 
available to obtain our measures of misallocation, we end up with a dataset with a maximum of 62 countries, a minimum of 20,691 firms, and a maximum of $28,022 .^{10}$ Note, however, that when we calculate measures of misallocation we may trim the available sample for outliers further and would be left with fewer observations. We will indicate below any further trimming implemented.

Table 1 presents the list of countries, the number of firms, and their distribution by size when we use the sample of 26,498 firms that results from the calculation of the TFPR measure. Size is defined as small for firms with less than 20 employees, medium if it has between 20 and 99 employees, and large if they have more than 100 employees. There are 13 Asian countries in the sample highlighted in bold. However, for several of them such as Kazakhstan, Mongolia, Myanmar, Nepal, Pakistan, and Sri Lanka, the number of observations is relatively small. In general, the sample is almost evenly distributed by firm sizes. However, given the prevalence of small firms in these countries, large firms are overrepresented. The World Bank argues that this is the case since larger firms tend to have a larger impact on employment creation. Finally, India, followed by Bangladesh, the PRC, and Egypt are the countries with the largest number of observations and together make up around $28 \%$ of the sample of firms.

Table 1: Number of Firms and Distribution by Size

\begin{tabular}{|c|c|c|c|c|c|c|c|c|c|}
\hline \multirow[b]{2}{*}{ Country } & \multirow[b]{2}{*}{ No. of Firms } & \multicolumn{3}{|c|}{$\%$ by size } & \multirow[b]{2}{*}{ Country } & \multirow[b]{2}{*}{ No. of Firms } & \multicolumn{3}{|c|}{ \% by size } \\
\hline & & Small & Medium & Large & & & Small & Medium & Large \\
\hline Angola & 174 & 84.5 & 13.2 & 2.3 & Liberia & 135 & 77.8 & 14.8 & 7.4 \\
\hline Argentina & 539 & 25.4 & 39.3 & 35.3 & Mali & 258 & 78.3 & 19.4 & 2.3 \\
\hline Bangladesh & 1470 & 29.1 & 31.1 & 39.9 & Mauritius & 104 & 44.2 & 38.5 & 17.3 \\
\hline Bolivia & 213 & 49.8 & 36.2 & 14.1 & Mexico & 989 & 33.5 & 33.5 & 33.1 \\
\hline Brazil & 949 & 34.3 & 45.1 & 20.7 & Moldova & 103 & 27.2 & 41.8 & 31.1 \\
\hline Bulgaria & 370 & 31.6 & 46.8 & 21.6 & Mongolia & 121 & 24.8 & 47.9 & 27.3 \\
\hline Chile & 578 & 29.4 & 41.0 & 29.6 & Mozambique & 275 & 63.3 & 30.6 & 6.2 \\
\hline PRC & 1387 & 13.1 & 42.8 & 44.1 & Myanmar & 135 & 44.4 & 25.9 & 29.6 \\
\hline Colombia & 559 & 32.4 & 36.1 & 31.5 & Nepal & 179 & 33.5 & 46.4 & 20.1 \\
\hline Costa Rica & 183 & 34.4 & 43.7 & 21.9 & Nicaragua & 219 & 62.1 & 31.5 & 6.4 \\
\hline Croatia & 217 & 35.5 & 31.8 & 32.7 & Pakistan & 136 & 38.2 & 40.4 & 21.3 \\
\hline Cote d'Ivoire & 110 & 55.5 & 28.2 & 16.4 & Paraguay & 111 & 41.4 & 49.6 & 9.0 \\
\hline DRC & 146 & 63.0 & 30.8 & 6.2 & Peru & 485 & 25.0 & 40.2 & 34.9 \\
\hline Ecuador & 228 & 40.8 & 36.4 & 22.8 & Philippines & 436 & 22.0 & 46.1 & 31.9 \\
\hline Egypt & 1363 & 36.4 & 39.7 & 23.9 & Romania & 103 & 33.0 & 42.7 & 24.3 \\
\hline El Salvador & 294 & 35.0 & 37.8 & 27.2 & Russian Federation & 444 & 35.6 & 41.7 & 22.8 \\
\hline Gabon & 104 & 67.3 & 26.0 & 6.7 & Senegal & 216 & 76.4 & 16.7 & 6.9 \\
\hline Ghana & 265 & 63.0 & 26.0 & 10.9 & Serbia & 107 & 26.2 & 36.5 & 37.4 \\
\hline Guatemala & 252 & 40.5 & 36.9 & 22.6 & Sierra Leone & 143 & 74.1 & 18.2 & 7.7 \\
\hline Guinea & 103 & 83.5 & 10.7 & 5.8 & South Africa & 651 & 33.2 & 40.7 & 26.1 \\
\hline Honduras & 200 & 52.5 & 30.5 & 17.0 & Sri Lanka & 239 & 50.2 & 28.9 & 20.9 \\
\hline India & 4698 & 28.8 & 46.2 & 25.0 & Tanzania & 242 & 49.2 & 34.3 & 16.5 \\
\hline Indonesia & 549 & 46.5 & 28.8 & 24.8 & Tunisia & 271 & 17.7 & 44.7 & 37.6 \\
\hline Iraq & 466 & 75.3 & 23.6 & 1.1 & Turkey & 431 & 23.2 & 40.8 & 36.0 \\
\hline Israel & 123 & 43.9 & 42.3 & 13.8 & Uganda & 263 & 57.4 & 34.2 & 8.4 \\
\hline Jordan & 252 & 36.5 & 33.7 & 29.8 & Ukraine & 250 & 47.6 & 34.8 & 17.6 \\
\hline Kazakhstan & 119 & 23.5 & 37.0 & 39.5 & Uruguay & 161 & 44.7 & 45.3 & 9.9 \\
\hline Kenya & 386 & 28.5 & 37.8 & 33.7 & Viet Nam & 614 & 13.7 & 41.0 & 45.3 \\
\hline Lao PDR & 318 & 46.9 & 35.5 & 17.6 & Zambia & 287 & 45.3 & 37.3 & 17.4 \\
\hline Lebanon & 133 & 39.1 & 40.6 & 20.3 & Zimbabwe & 349 & 34.4 & 37.3 & 28.4 \\
\hline
\end{tabular}

DRC = Democratic Republic of the Congo, Lao PDR = Lao People's Democratic Republic, PRC = People's Republic of China.

Source: Author's calculation from the World Bank Enterprise Survey data.

10 Observations vary depending on the variable of interest. For instance, calculating the log of MRPK leads to less observations as there are missing data for more firms. 
The institutional obstacles variables also come from the surveys. Firms are asked, for each of the modules of the interview, to answer "How much of an obstacles is..." a particular aspect of their operations such as customs and trade regulations, labor regulations, or access to finance. Firms are asked to choose between "no obstacle," "minor obstacle," "moderate obstacle," "major obstacle," and "very severe obstacle." We translate these into a numeric, binomial variable taking the value of 0 for no obstacle, minor, and moderate obstacle, and 1 for major and very severe obstacle. We also do a robustness check by classifying moderate obstacle as 1 rather than 0 . Table 2 displays the list of obstacles available in the surveys. These obstacles can be classified into infrastructure (transportation, electricity); goods markets (trade regulations, informal sector); taxation and licensing; insecurity (political instability, corruption, theft, corruption and courts); labor market (regulations and skill inadequacy); and access to finance. These obstacles could affect the optimal size of firms and hence the dispersion of their marginal products, as they can affect different firms heterogeneously and can act as wedges that prevent firms from growing to their optimal size. The third column in Table 2 reports the percentage of firms in all available countries that declare each obstacle as major or very severe. The obstacles with higher incidence are electricity supply, corruption, tax rates, and political instability. Those with the lowest incidence frequency are customs and trade regulations, courts, and labor regulations.

Table 2: List of Institutional Obstacles

\begin{tabular}{clc}
\hline Label & \multicolumn{1}{c}{ Description } & $\begin{array}{c}\text { \% of firms } \\
\text { declaring } \\
\text { obstacle }\end{array}$ \\
\hline $\mathrm{c} 30 \mathrm{a}$ & How much of an obstacle is electricity to the current operations of this firm? & 0.387 \\
$\mathrm{~d} 30 \mathrm{a}$ & How much of an obstacle is transportation of goods, supplies, and inputs? & 0.171 \\
$\mathrm{~d} 30 \mathrm{~b}$ & How much of an obstacle are customs and trade regulations? & 0.114 \\
e30 & How much of an obstacle are the informal competitors to your operations? & 0.244 \\
g30a & How much of an obstacle is access to land the operations of this firm? & 0.170 \\
i30 & How much of an obstacle are crime, theft disorder to this establishment? & 0.165 \\
j30a & How much of an obstacle are tax rates & 0.315 \\
j30b & How much of an obstacle are tax administrations & 0.208 \\
j30c & How much of an obstacle is business licensing and permits & 0.146 \\
j30e & How much of an obstacle is political instability & 0.302 \\
j30f & How much of an obstacle is corruption & 0.365 \\
h30 & How much of an obstacle are courts & 0.122 \\
k30 & How much of an obstacle is access to finance & 0.249 \\
130a & How much of an obstacle are labor regulations to the operations of this firm? & 0.128 \\
I30b & How much of an obstacle is inadequately educated workforce to your firm? & 0.199 \\
\hline
\end{tabular}

Source: Author's calculation from the World Bank Enterprise Survey data. 


\section{RESULTS}

\section{A. Measures of Misallocation}

We first start by calculating the measures of misallocation at the country level, i.e., the dispersion measures and the OP covariance terms. Table 3 reports summary statistics for the three measures and Figure 1 reports their distribution across countries. Finally, Table 4 reports the correlation coefficients between them.

Table 3: Summary Statistics of Misallocation Measures

\begin{tabular}{lcccc}
\hline & Mean & Std. Dev. & Min & Max \\
\hline $\operatorname{SD}(M R P K)$ & 1.7246 & 0.3341 & 1.2326 & 2.5800 \\
$\operatorname{SD}\left(\tau_{y}\right)$ & 1.6288 & 0.2887 & 0.7257 & 2.3836 \\
$\operatorname{SD}\left(\tau_{k}\right)$ & 1.3958 & 0.3582 & 0.8579 & 3.0764 \\
$\operatorname{Cov}(\log [\mathrm{Y} / \mathrm{L}], \mathrm{Li} / \mathrm{L})$ & 0.0007 & 0.0020 & -0.0079 & 0.0074 \\
$\operatorname{Cov}(\log [\mathrm{TFPR}], \mathrm{VAi} / \mathrm{VA})$ & 0.0083 & 0.0112 & -0.0078 & 0.0591 \\
\hline
\end{tabular}

Source: Author's calculation from the World Bank Enterprise Survey data.

Table 4: Correlation between Misallocation Measures

\begin{tabular}{lccccc}
\hline & $\operatorname{Cov}(\log [\mathrm{Y} / \mathrm{L}], \mathrm{Li} / \mathrm{L})$ & $\operatorname{Cov}(\log [\mathrm{TFPR}], \mathrm{VAi} / \mathrm{VA})$ & $\mathrm{SD}(\mathrm{MRPK})$ & $\mathrm{SD}\left(\tau_{\mathrm{y}}\right)$ & $\mathrm{SD}\left(\tau_{\mathrm{k}}\right)$ \\
\hline $\operatorname{Cov}(\log [\mathrm{Y} / \mathrm{L}], \mathrm{Li} / \mathrm{L})$ & 1.000 & & & & \\
$\operatorname{Cov}(\log [\mathrm{TFPR}], \mathrm{VAi} / \mathrm{VA})$ & -0.038 & 1.000 & & & \\
$\operatorname{SD}(\mathrm{MRPK})$ & 0.403 & 0.108 & 1.000 & & \\
$\operatorname{SD}\left(\tau_{y}\right)$ & 0.144 & 0.170 & 0.315 & 1.000 & \\
$\operatorname{SD}\left(\tau_{k}\right)$ & 0.476 & -0.067 & 0.565 & 0.544 & 1.000 \\
\hline
\end{tabular}

Source: Author's calculation from the World Bank Enterprise Survey data.

Figure 1: Distribution of Measures of Misallocation
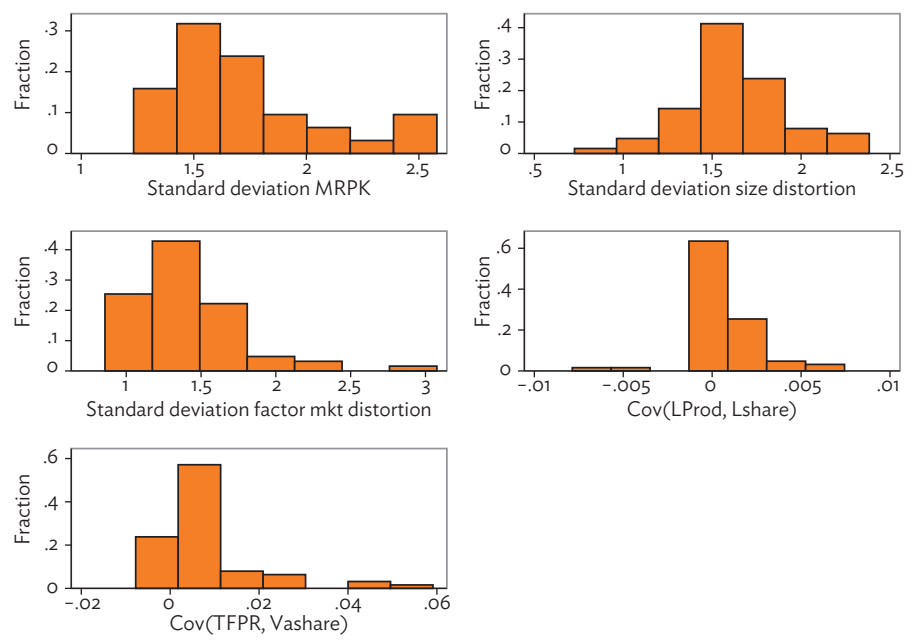

Source: Author's calculation from the World Bank Enterprise Survey data. 
Of all measures of misallocation, the dispersion of MRPK shows more variation across countries with a mean value of around 1.7. This is similar to the dispersion found by Kalemli-Ozcan and Sorensen (2012) for their sample of African countries. Size distortions appear to have a lager average standard deviation than factor market distortions. The country with the lowest and highest factor market distortion dispersions are South Africa in 2007 and Gabon in 2009, respectively. For size distortions, Angola in 2006 displays the lowest and Cote d'lvoire the largest dispersion. Of the Asian countries, Pakistan, Lao People's Democratic, and Indonesia tend to display the largest distortions. Those for the PRC and India tend to be more moderate, especially in the case of $\tau_{k}$. Our measures of dispersion appear to be larger than those reported for the PRC and India by Hsieh and Klenow (2009) and by Ha and Kiyota (2015) for Viet Nam. For instance, for Viet Nam, Ha and Kiyota (2015) find a standard deviation of TFPR of 0.79 , whereas we find (not reported) a value of 1.13 . One of the main reasons beyond obvious differences in data sources is that their data allows them to introduce a higher level of heterogeneity by sector when calculating TFPR, which then reduces dispersion. Given the limited number of observations per country in our sample, it is not possible to undertake such industry-level analysis. Nevertheless, the dispersion in the distortions faced in our sample of countries is large, indicating very large potential growth gains from reallocation.

The covariance measure is very tightly concentrated around zero for both labor productivity and TFP. The labor productivity measure appears to be more normally distributed whereas the TFP measure appears to be truncated and skewed toward positive values. The measures, however, vary very little. The maximum covariance found is 0.06 (i.e., 6\%) for the case of Romania in 2013. Bartelsman, Haltiwanger, and Scarpetta (2013), using a different dataset, find a value of -0.03 for that country but for a sample covering 1993-2001. Our findings indicate that, for the majority of countries, firm sizes are allocated in terms of productivity no better than random. Such a tight distribution around zero may, however, be affected by the sampling of firms carried out to construct the dataset. Since we do not observe all the firms in the economy, the choice of stratified sampling techniques based on firm sizes can affect the covariance measure. For this reason, the results for these measures should be treated with caution. It is likely that, given the little variability of these measures across countries, they will be very difficult to predict by other observables. Comprehensive firm-level data for a large number of Asian countries would allow us to reach firmer conclusions. Nevertheless, and given the sample of developing countries we are working with, the covariance measures show a high degree of misallocation.

The correlations reported in Table 4 also show that the covariance measures, especially the covariance between log TFPR and value-added shares, display a low level of correlation with other measures. The Hsieh-Klenow type measures, are more strongly positively correlated as could be expected.

\section{B. Obstacles and Misallocation: Country-Level Evidence}

We now assess whether our measures of dispersion and covariance correlate with declared institutional obstacles at the country level. To do so, we regress the five available measures on obstacles where, at the country level, the obstacle is measured as the percentage of firms that declare the specific obstacle to be major or severe. Due to the limited number of cross-country observations, the results are just indicative of the relevance of certain distortions. Any obstacles that increase dispersion significantly then increases misallocation. Obstacles that increase the covariance measures, however, reduce misallocation. Note that some variables may not necessarily increase misallocation just because they are considered as obstacles by firms. If certain regulations interact with an already 
distorted allocation, they may lead to a reduced dispersion of MRPKs, for instance. Because the number of firms used for each country is different, the results are obtained using weighted least squares where the weights are given by the percentage of firms of each country in the sample. All regressions below use heteroscedasticity-consistent standard errors.

Table 5 displays the cross-country results. Perhaps unsurprisingly, given their distribution, the covariance measures do not appear to be strongly correlated with obstacles in the cross section of countries. This is especially so for the TFPR measure, where no obstacle appears to be statistically significant. For the covariance between labor productivity and employment share, access to land reduces the covariance, whilst access to finance increases it. The effects, however, are quantitatively small and only significant at the 10\% level. The factor market distortion dispersion measure in the fourth column displays similar results. In this case, only inadequate education of the labor force appears to have a strong explanatory effect and it increases the dispersion of the idiosyncratic factor market distortion. For the size distortion (third column) both crime and theft and courts appear to have a significantly positive impact on its standard deviation. Finally, for the dispersion of the MRPK, several variables appear to have a strong explanatory power. Inadequate education and courts both appear strongly significant. Courts, however, appear to reduce, rather than increase misallocation. Customs and trade regulations and crime and theft both increase misallocation significantly, whereas access to land and labor regulations appear to reduce it for this cross section of developing countries. The results, however, and as commented above, should be taken with caution given the small number of observations.

Table 5: Cross-Country Regression: Measures of Misallocation on Obstacles

\begin{tabular}{|c|c|c|c|c|c|}
\hline Dep. Var: & $S D(\log M R P K)$ & $\operatorname{SD}\left(\log \tau_{y}\right)$ & $\operatorname{SD}\left(\log \tau_{k}\right)$ & $\begin{array}{l}\text { Covariance } \\
(Y / L, L \text { share })\end{array}$ & $\begin{array}{c}\text { Covariance } \\
\text { (TFPR, VA share) }\end{array}$ \\
\hline \multirow[t]{2}{*}{ Electricity } & 0.245 & 0.0510 & -0.0576 & 0.00148 & -0.00607 \\
\hline & $(0.94)$ & $(0.32)$ & $(-0.24)$ & (1.35) & $(-0.73)$ \\
\hline \multirow[t]{2}{*}{ Transportation } & -0.575 & -0.144 & 0.763 & 0.00355 & 0.00684 \\
\hline & $(-1.41)$ & $(-0.27)$ & $(1.32)$ & (1.33) & (0.37) \\
\hline \multirow[t]{2}{*}{ Customs and trade reg } & $1.281^{*}$ & -0.107 & 1.107 & -0.00253 & 0.0171 \\
\hline & $(2.32)$ & $(-0.15)$ & (1.38) & $(-0.69)$ & $(0.72)$ \\
\hline \multirow[t]{2}{*}{ Informal sector } & -0.553 & -0.437 & -0.303 & -0.00105 & 0.0170 \\
\hline & $(-1.62)$ & $(-1.24)$ & $(-0.74)$ & $(-0.56)$ & $(1.32)$ \\
\hline \multirow[t]{2}{*}{ Access to land } & $-1.141^{*}$ & -0.000425 & -0.174 & $-0.00591^{*}$ & -0.00369 \\
\hline & $(-2.30)$ & $(-0.00)$ & $(-0.34)$ & $(-2.50)$ & $(-0.23)$ \\
\hline \multirow[t]{2}{*}{ Crime, theft } & $0.799^{*}$ & $0.763^{* *}$ & -0.0741 & -0.000831 & 0.0000519 \\
\hline & (2.69) & $(3.44)$ & $(-0.20)$ & $(-0.48)$ & $(0.00)$ \\
\hline \multirow[t]{2}{*}{ Tax rates } & -0.0853 & 0.283 & 0.305 & -0.00282 & 0.00104 \\
\hline & $(-0.31)$ & $(0.88)$ & $(0.86)$ & $(-1.73)$ & (0.09) \\
\hline \multirow[t]{2}{*}{ Tax administration } & 0.702 & 0.307 & -0.151 & 0.00557 & -0.00471 \\
\hline & $(1.23)$ & $(0.54)$ & $(-0.24)$ & (1.96) & $(-0.24)$ \\
\hline \multirow[t]{2}{*}{ Business licensing } & -0.449 & -1.248 & 0.00866 & -0.00585 & -0.0201 \\
\hline & $(-0.76)$ & $(-1.18)$ & (0.01) & $(-1.48)$ & $(-0.76)$ \\
\hline \multirow[t]{2}{*}{ Political instability } & -0.135 & -0.0656 & 0.411 & -0.000425 & -0.00521 \\
\hline & $(-0.86)$ & $(-0.41)$ & $(1.86)$ & $(-0.42)$ & $(-0.75)$ \\
\hline \multirow[t]{2}{*}{ Corruption } & -0.00373 & 0.0532 & -0.458 & 0.00108 & 0.00659 \\
\hline & $(-0.01)$ & (0.19) & $(-1.42)$ & $(0.73)$ & (0.64) \\
\hline \multirow[t]{2}{*}{ Courts } & $-1.364^{* * *}$ & $0.844^{*}$ & -1.057 & 0.000312 & -0.0100 \\
\hline & $(-3.88)$ & (2.14) & $(-1.94)$ & $(0.12)$ & $(-0.58)$ \\
\hline \multirow[t]{2}{*}{ Access to finance } & 0.223 & -0.223 & -0.244 & $0.00374^{*}$ & 0.00981 \\
\hline & $(0.59)$ & $(-0.50)$ & $(-0.62)$ & $(2.02)$ & $(0.76)$ \\
\hline
\end{tabular}


Table 5 continued

\begin{tabular}{|c|c|c|c|c|c|}
\hline Dep. Var: & $S D(\log M R P K)$ & $\operatorname{SD}\left(\log \tau_{y}\right)$ & $S D\left(\log \tau_{k}\right)$ & $\begin{array}{c}\text { Covariance } \\
(\mathrm{Y} / \mathrm{L}, \mathrm{L} \text { share })\end{array}$ & $\begin{array}{c}\text { Covariance } \\
\text { (TFPR, VA share) }\end{array}$ \\
\hline Labor regulations & $\begin{array}{l}-1.116^{*} \\
(-2.28)\end{array}$ & $\begin{array}{l}0.400 \\
(0.72)\end{array}$ & $\begin{array}{l}-0.797 \\
(-1.34)\end{array}$ & $\begin{array}{r}-0.00123 \\
(-0.44)\end{array}$ & $\begin{array}{r}-0.0236 \\
(-1.24)\end{array}$ \\
\hline Inadequate education & $\begin{array}{r}1.519^{* * *} \\
(3.73)\end{array}$ & $\begin{array}{r}0.128 \\
(0.32)\end{array}$ & $\begin{array}{l}1.391^{* *} \\
(3.05)\end{array}$ & $\begin{array}{r}0.00217 \\
(1.04)\end{array}$ & $\begin{array}{r}0.0233 \\
(1.66)\end{array}$ \\
\hline Constant & $\begin{array}{r}1.644^{* * *} \\
(16.99) \\
\end{array}$ & $\begin{array}{r}1.544^{* * *} \\
(10.86) \\
\end{array}$ & $\begin{array}{l}1.168^{* * *} \\
(12.07)\end{array}$ & $\begin{array}{r}-0.0000659 \\
(-0.15) \\
\end{array}$ & $\begin{array}{r}-0.000300 \\
(-0.10) \\
\end{array}$ \\
\hline $\begin{array}{l}N \\
R^{2}\end{array}$ & $\begin{array}{r}60 \\
0.458 \\
\end{array}$ & $\begin{array}{r}62 \\
0.418 \\
\end{array}$ & $\begin{array}{r}62 \\
0.320 \\
\end{array}$ & $\begin{array}{r}62 \\
0.333 \\
\end{array}$ & $\begin{array}{r}60 \\
0.253 \\
\end{array}$ \\
\hline
\end{tabular}

Notes: t-statistics in parentheses. ${ }^{*} p<0.10,{ }^{* *} p<0.05,{ }^{* *} p<0.01$. Heteroscedasticity-consistent standard errors. All regressions using weighted least squares using number of firms as weights.

Source: Author's calculation from the World Bank Enterprise Survey data.

\section{Obstacles and Misallocation: Firm-Level Evidence}

We now look at the firm-level data to understand how obstacles determine distortions focusing on the Hsieh-Klenow measures. "If factor cost shares and MRPKs were equal for all firms, then they should not be predictable. Thus, following Kalemli-Ozcan and Sorensen (2012), if there is misallocation and this is related to firms' declared obstacles, then we would expect these obstacles to be good predictors of distortions. We then look at whether institutional obstacles are significant predictors of distortions and the sign of the effect. For MRPK, a positive sign indicates that the effect of moving from a firm with no declared obstacle to a firm with a declared obstacle is an increase in the MRPK. In theory, this can come about by an increase in capital distortions, or an increase in size distortions. The coefficient value indicates the per unit change in MRPK from moving from firms with no obstacles to firms with obstacles. ${ }^{12}$ For the regressions separating the two distortions, the interpretation is as follows. For the size distortion $\left(\tau_{y}\right)$ regressions, a positive coefficient implies a lower $\tau_{y}$, i.e., the distortion acts as a subsidy to size. For the factor market distortion $\left(\tau_{k}\right)$ regressions, a positive coefficient implies a higher $\tau_{k}$, i.e., the distortion acts as a tax on capital relative to labor. We present regressions with and without country dummies, and we also control for firm size (the log of the number of employees) in several specifications.

Tables 6,7 , and 8 present the results for the three measures of distortions and different specifications. The results in Table 6 show that the main obstacles driving misallocation change substantially when we include country dummies. The way we interpret this result is that some obstacles are better at explaining the cross-country variation in distortions (regressions with no country dummies) and some obstacles are better at explaining the distortions within countries (regressions with country dummies). Also, estimates of the size distortion regressions are more precise than those for MRPK and factor market distortions. Overall, size appears to have a positive impact on the MRPK: larger firms tend to face either larger size or larger capital distortions leading to higher marginal products. Transportation, crime and theft, tax rates, and labor market obstacles all have a positive impact in the regressions with no country dummies, but turn insignificant when we include them. It is likely that these obstacles related to infrastructure and the political environment are more country specific rather than firm specific, turning them important explanatory variables at the country level. Likewise, political instability appears to have a

1 We cannot obtain firm-level results for the covariance measures since they are aggregate. An alternative route would be to regress firm sizes on obstacles and compute the covariance of this residual with a measure of productivity. This can then be compared with the unconditional covariance between size and productivity to assess the aggregate gains from controlling for obstacles. However, the fact that the original covariances were very tightly distributed around zero renders these comparisons not reliable.

12 Hence, the percentage change is the coefficient times 100. 
strong negative effect on MRPK. As we will see later on, this is mainly driven by the fact that political instability acts as a size tax preventing firms from acquiring their optimal size. For the regressions containing country dummies, the results point toward the informal sector, access to land, courts, and access to finance as main obstacles. All of them except for access to land have a negative impact on MRPK, indicating that they either act as a relative tax on capital or on size. Access to land, however, has a positive effect associated, as we will see below, to an increase in the size tax.

Table 6: Firm-Level Regression of log MRPK on Obstacles

\begin{tabular}{|c|c|c|c|c|}
\hline Dep. Var: & $\log$ MRPK & $\log$ MRPK & $\log$ MRPK & $\log$ MRPK \\
\hline Electricity & $\begin{array}{r}-0.0364 \\
(-1.35)\end{array}$ & $\begin{array}{r}-0.0236 \\
(-0.81)\end{array}$ & $\begin{array}{r}-0.0208 \\
(-0.78)\end{array}$ & $\begin{array}{r}-0.0259 \\
(-0.90)\end{array}$ \\
\hline Transportation & $\begin{array}{r}0.118^{* *} \\
(3.23)\end{array}$ & $\begin{array}{r}0.0396 \\
(1.11)\end{array}$ & $\begin{array}{c}0.107^{* *} \\
(2.94)\end{array}$ & $\begin{array}{r}0.0219 \\
(0.61)\end{array}$ \\
\hline Customs and trade reg & $\begin{array}{l}0.0215 \\
(0.52)\end{array}$ & $\begin{array}{r}0.0269 \\
(0.67)\end{array}$ & $\begin{array}{r}0.00638 \\
(0.16)\end{array}$ & $\begin{array}{r}0.00222 \\
(0.06)\end{array}$ \\
\hline Informal sector & $\begin{array}{r}-0.0568 \\
(-1.87)\end{array}$ & $\begin{array}{r}-0.103^{* * *} \\
(-3.35)\end{array}$ & $\begin{array}{r}-0.0369 \\
(-1.21)\end{array}$ & $\begin{array}{r}-0.0818^{* *} \\
(-2.67)\end{array}$ \\
\hline Access to land & $\begin{array}{r}0.0204 \\
(0.57)\end{array}$ & $\begin{array}{r}0.116^{* * *} \\
(3.33)\end{array}$ & $\begin{array}{r}0.0335 \\
(0.94)\end{array}$ & $\begin{array}{r}0.136^{* * *} \\
(3.93)\end{array}$ \\
\hline Crime, theft & $\begin{array}{r}0.173^{* * *} \\
(4.57)\end{array}$ & $\begin{array}{r}0.0545 \\
(1.42)\end{array}$ & $\begin{array}{r}0.188^{* * *} \\
(4.99)\end{array}$ & $\begin{array}{r}0.0615 \\
(1.62)\end{array}$ \\
\hline Tax rates & $\begin{array}{r}0.0948^{* *} \\
(3.06)\end{array}$ & $\begin{array}{r}0.0143 \\
(0.46)\end{array}$ & $\begin{array}{r}0.0891^{* *} \\
(2.89)\end{array}$ & $\begin{array}{r}0.00396 \\
(0.13)\end{array}$ \\
\hline Tax administration & $\begin{array}{r}-0.0475 \\
(-1.29)\end{array}$ & $\begin{array}{r}-0.0388 \\
(-1.07)\end{array}$ & $\begin{array}{r}-0.0457 \\
(-1.25)\end{array}$ & $\begin{array}{r}-0.0332 \\
(-0.93)\end{array}$ \\
\hline Business licensing & $\begin{array}{r}-0.0330 \\
(-0.86)\end{array}$ & $\begin{array}{r}-0.0749^{*} \\
(-2.02)\end{array}$ & $\begin{array}{r}-0.0331 \\
(-0.87)\end{array}$ & $\begin{array}{r}-0.0761^{*} \\
(-2.07)\end{array}$ \\
\hline Political instability & $\begin{array}{r}-0.246^{* * *} \\
(-7.90)\end{array}$ & $\begin{array}{r}-0.0154 \\
(-0.44)\end{array}$ & $\begin{array}{r}-0.253^{* * *} \\
(-8.18)\end{array}$ & $\begin{array}{r}-0.0276 \\
(-0.80)\end{array}$ \\
\hline Corruption & $\begin{array}{r}-0.0672^{*} \\
(-2.22)\end{array}$ & $\begin{array}{r}0.0422 \\
(1.37)\end{array}$ & $\begin{array}{r}-0.0581 \\
(-1.94)\end{array}$ & $\begin{array}{r}0.0490 \\
(1.61)\end{array}$ \\
\hline Courts & $\begin{array}{r}0.00565 \\
(0.14)\end{array}$ & $\begin{array}{r}-0.128^{* *} \\
(-3.24)\end{array}$ & $\begin{array}{r}-0.0102 \\
(-0.26)\end{array}$ & $\begin{array}{r}-0.130^{* * *} \\
(-3.34)\end{array}$ \\
\hline Access to finance & $\begin{array}{r}-0.0459 \\
(-1.52)\end{array}$ & $\begin{array}{r}-0.109^{* * *} \\
(-3.58)\end{array}$ & $\begin{array}{r}-0.00982 \\
(-0.32)\end{array}$ & $\begin{array}{r}-0.0768^{*} \\
(-2.52)\end{array}$ \\
\hline Labor regulations & $\begin{array}{r}0.103^{* *} \\
(2.59)\end{array}$ & $\begin{array}{r}0.0531 \\
(1.35)\end{array}$ & $\begin{array}{r}0.0822^{*} \\
(2.10)\end{array}$ & $\begin{array}{r}0.0344 \\
(0.88)\end{array}$ \\
\hline Inadequate education & $\begin{array}{r}0.133^{* * *} \\
(3.88)\end{array}$ & $\begin{array}{r}-0.0128 \\
(-0.37)\end{array}$ & $\begin{array}{r}0.120^{* * *} \\
(3.56)\end{array}$ & $\begin{array}{r}-0.0229 \\
(-0.68)\end{array}$ \\
\hline $\log$ (No. of employees) & & & $\begin{array}{r}0.0861^{* * *} \\
(9.39)\end{array}$ & $\begin{array}{c}0.118^{* * *} \\
(12.47)\end{array}$ \\
\hline Constant & $\begin{array}{r}0.663^{* * *} \\
(35.12)\end{array}$ & $\begin{array}{r}-0.0764 \\
(-0.40)\end{array}$ & $\begin{array}{r}0.334^{* * *} \\
(8.24)\end{array}$ & $\begin{array}{r}-0.567^{* *} \\
(-2.92)\end{array}$ \\
\hline Country dummies & $\mathrm{NO}$ & YES & $\mathrm{NO}$ & YES \\
\hline $\begin{array}{l}\mathrm{N} \\
\mathrm{R}^{2}\end{array}$ & $\begin{array}{r}20706 \\
0.008 \\
\end{array}$ & $\begin{array}{r}20706 \\
0.088 \\
\end{array}$ & $\begin{array}{r}20691 \\
0.013 \\
\end{array}$ & $\begin{array}{l}20691 \\
0.094 \\
\end{array}$ \\
\hline
\end{tabular}

Notes: t-statistics in parentheses. ${ }^{*} p<0.10,{ }^{* *} p<0.05,{ }^{* * *} p<0.01$. Heteroscedasticity-consistent standard errors.

Source: Author's calculation from the World Bank Enterprise Survey data.

The regression results for the size distortion measure are presented in Table 7 . The results reveal that several variables appear to be important determinants of size distortions both within and across countries. Infrastructure obstacles, such as electricity and transportation, and trade regulations have a positive impact. Recall that a positive coefficient for this measure implies that, moving from a firm with no obstacles to one with declared obstacles we reduce the size distortion (i.e., acting as a subsidy). This is 
a surprising result, then, given that infrastructure and trade barriers can act as an obstacle for firm expansion. Nevertheless, it may well be the case that firms grow larger than it would otherwise be optimal according to their productivity because they are either protected by weak infrastructure and trade regulations, or because they need to hire more factors of production to substitute for infrastructure. For instance, in the regression controlling for size and country dummies, countries facing important obstacles from customs and trade regulations have a total cost share of labor which is 10\% larger than for firms not facing these obstacles. Access to finance, on the other hand, acts as a significant size tax in all specifications. Tax administration, political instability, and corruption appear to reduce firm sizes relative to optimal, but they are only significant when we do not control for country effects. This is consistent with the results in Table 6 for political instability and corruption. Access to land appears to act as a size tax when we control for country effects, but as a subsidy when we do not. However, the results for this variable are not robust to the inclusion of size as a control.

\section{Table 7: Firm-Level Regression of $\log \left(\tau_{y}\right)$ on Obstacles}

\begin{tabular}{|c|c|c|c|c|}
\hline Dep. Var: & $\log \left(\tau_{y}\right)$ & $\log \left(\tau_{y}\right)$ & $\log \left(\tau_{y}\right)$ & $\log \left(\tau_{y}\right)$ \\
\hline Electricity & $\begin{array}{r}0.299^{* * *} \\
(7.87)\end{array}$ & $\begin{array}{r}-0.00183 \\
(-0.07)\end{array}$ & $\begin{array}{r}0.454^{* * *} \\
(13.52)\end{array}$ & $\begin{array}{r}-0.0502^{* *} \\
(-3.09)\end{array}$ \\
\hline Transportation & $\begin{array}{r}0.596^{* * *} \\
(11.46)\end{array}$ & $\begin{array}{r}0.172^{* * *} \\
(5.07)\end{array}$ & $\begin{array}{r}0.549^{* * *} \\
(11.77)\end{array}$ & $\begin{array}{r}0.0421^{*} \\
(2.07)\end{array}$ \\
\hline Customs and trade reg & $\begin{array}{r}0.479^{* * *} \\
(8.28)\end{array}$ & $\begin{array}{r}0.398^{* * *} \\
(10.33)\end{array}$ & $\begin{array}{r}0.248^{* * *} \\
(4.81)\end{array}$ & $\begin{array}{r}0.109^{* * * *} \\
(4.71)\end{array}$ \\
\hline Informal sector & $\begin{array}{r}-0.196^{* * *} \\
(-4.35)\end{array}$ & $\begin{array}{r}-0.244^{* * * *} \\
(-8.60)\end{array}$ & $\begin{array}{r}0.0573 \\
(1.41)\end{array}$ & $\begin{array}{r}-0.0153 \\
(-0.91)\end{array}$ \\
\hline Access to land & $\begin{array}{r}0.0934 \\
(1.78)\end{array}$ & $\begin{array}{r}-0.166^{* * *} \\
(-5.03)\end{array}$ & $\begin{array}{r}0.237^{* * *} \\
(5.00)\end{array}$ & $\begin{array}{r}0.000722 \\
(0.04)\end{array}$ \\
\hline Crime, theft & $\begin{array}{r}-0.429^{* * *} \\
(-7.85)\end{array}$ & $\begin{array}{r}-0.0811^{*} \\
(-2.20)\end{array}$ & $\begin{array}{r}-0.290^{* * *} \\
(-5.84)\end{array}$ & $\begin{array}{r}-0.00974 \\
(-0.42)\end{array}$ \\
\hline Tax rates & $\begin{array}{r}-0.0615 \\
(-1.43)\end{array}$ & $\begin{array}{r}0.0339 \\
(1.15)\end{array}$ & $\begin{array}{r}-0.0325 \\
(-0.86)\end{array}$ & $\begin{array}{r}-0.00421 \\
(-0.25)\end{array}$ \\
\hline Tax administration & $\begin{array}{r}-0.145^{* *} \\
(-2.82)\end{array}$ & $\begin{array}{r}0.0205 \\
(0.58)\end{array}$ & $\begin{array}{r}-0.144^{* *} \\
(-3.18)\end{array}$ & $\begin{array}{r}0.0422^{*} \\
(2.07)\end{array}$ \\
\hline Business licensing & $\begin{array}{r}-0.0740 \\
(-1.35)\end{array}$ & $\begin{array}{l}-0.101^{* *} \\
(-2.80)\end{array}$ & $\begin{array}{r}-0.0189 \\
(-0.39)\end{array}$ & $\begin{array}{r}-0.0704^{* *} \\
(-3.15)\end{array}$ \\
\hline Political instability & $\begin{array}{c}-0.974^{* * *} \\
(-22.62)\end{array}$ & $\begin{array}{r}-0.0267 \\
(-0.79)\end{array}$ & $\begin{array}{l}-1.014^{* * *} \\
(-26.52)\end{array}$ & $\begin{array}{l}0.0125 \\
(0.62)\end{array}$ \\
\hline Corruption & $\begin{array}{r}-0.153^{* * *} \\
(-3.65)\end{array}$ & $\begin{array}{r}0.00489 \\
(0.16)\end{array}$ & $\begin{array}{r}-0.124^{* * *} \\
(-3.39)\end{array}$ & $\begin{array}{r}0.0178 \\
(1.00)\end{array}$ \\
\hline Courts & $\begin{array}{r}0.175^{* *} \\
(2.98)\end{array}$ & $\begin{array}{l}0.101^{*} \\
(2.46)\end{array}$ & $\begin{array}{r}-0.00969 \\
(-0.19)\end{array}$ & $\begin{array}{l}0.0153 \\
(0.64)\end{array}$ \\
\hline Access to finance & $\begin{array}{r}-0.314^{* * *} \\
(-7.18)\end{array}$ & $\begin{array}{r}-0.430^{* * *} \\
(-15.09)\end{array}$ & $\begin{array}{r}-0.120^{* *} \\
(3.01)\end{array}$ & $\begin{array}{r}-0.105^{* * *} \\
(-6.06)\end{array}$ \\
\hline Labor regulations & $\begin{array}{l}0.107 \\
(1.79)\end{array}$ & $\begin{array}{r}0.244^{* * *} \\
(6.01)\end{array}$ & $\begin{array}{r}-0.145^{* *} \\
(-2.75)\end{array}$ & $\begin{array}{r}0.0601^{*} \\
(2.50)\end{array}$ \\
\hline Inadequate education & $\begin{array}{r}0.0394 \\
(0.75)\end{array}$ & $\begin{array}{r}0.185^{* * *} \\
(5.48)\end{array}$ & $\begin{array}{r}-0.156^{* * *} \\
(-3.34)\end{array}$ & $\begin{array}{r}0.0296 \\
(1.47)\end{array}$ \\
\hline $\log ($ No. of employees $)$ & & & $\begin{array}{r}0.912^{* * *} \\
(77.10)\end{array}$ & $\begin{array}{c}1.037^{* * *} \\
(184.39)\end{array}$ \\
\hline Constant & $\begin{array}{c}13.94^{* * *} \\
(500.42)\end{array}$ & $\begin{array}{r}10.03^{* * *} \\
(75.68)\end{array}$ & $\begin{array}{r}10.43^{* * *} \\
(208.89)\end{array}$ & $\begin{array}{r}7.995^{* * *} \\
(73.02)\end{array}$ \\
\hline Country dummies & NO & YES & NO & YES \\
\hline $\mathrm{N}$ & 21539 & 21539 & 21531 & 21531 \\
\hline$R^{2}$ & 0.051 & 0.614 & 0.273 & 0.873 \\
\hline
\end{tabular}


Finally, Table 8 displays the results for the relative capital to labor distortion. Four obstacles are significant drivers of this distortion across all specifications. These are customs and trade regulations, informal sector competition, courts, and access to finance. Trade regulations increase the relative cost share of capital, i.e., act as a tax on labor. The rest of these variables act as a tax on capital, implying that firms hire less capital than optimal reducing its cost share. Quantitatively, access to finance is the most important of them. Moving from firms that declare that finance is not an obstacle to firms that declare that finance is an obstacle, increases the cost share of labor relative to capital by close to $20 \%$. The effect of the informal sector may be the consequence of firms seeing their profits squeezed by informal competition, leading to difficulties to raise capital from credit markets. Finally, crime and theft and tax rates both act as a tax on capital but are only able to explain the cross-country variation of this distortion, rather than its within-country variability.

\section{Table 8: Firm-Level Regression of $\log \left(\tau_{k}\right)$ on Obstacles}

\begin{tabular}{|c|c|c|c|c|}
\hline Dep. Var: & $\log \left(\tau_{k}\right)$ & $\log \left(\tau_{k}\right)$ & $\log \left(\tau_{k}\right)$ & $\log \left(\tau_{k}\right)$ \\
\hline Electricity & $\begin{array}{r}-0.0271 \\
(-1.34)\end{array}$ & $\begin{array}{r}-0.0302 \\
(-1.35)\end{array}$ & $\begin{array}{r}-0.0347 \\
(-1.71)\end{array}$ & $\begin{array}{r}-0.0279 \\
(-1.25)\end{array}$ \\
\hline Transportation & $\begin{array}{r}-0.0169 \\
(-0.64)\end{array}$ & $\begin{array}{r}-0.0172 \\
(-0.63)\end{array}$ & $\begin{array}{r}-0.0149 \\
(-0.56)\end{array}$ & $\begin{array}{r}-0.0105 \\
(-0.38)\end{array}$ \\
\hline Customs and trade reg & $\begin{array}{r}-0.138^{* * *} \\
(-4.42)\end{array}$ & $\begin{array}{r}-0.133^{* * *} \\
(-4.28)\end{array}$ & $\begin{array}{r}-0.127^{* * *} \\
(-4.06)\end{array}$ & $\begin{array}{r}-0.118^{* * *} \\
(-3.80)\end{array}$ \\
\hline Informal sector & $\begin{array}{r}0.0707^{* *} \\
(3.12)\end{array}$ & $\begin{array}{r}0.0823^{* * *} \\
(3.46)\end{array}$ & $\begin{array}{r}0.0587^{* *} \\
(2.60)\end{array}$ & $\begin{array}{r}0.0701^{* *} \\
(2.95)\end{array}$ \\
\hline Access to land & $\begin{array}{r}0.0263 \\
(1.00)\end{array}$ & $\begin{array}{r}0.0108 \\
(0.40)\end{array}$ & $\begin{array}{r}0.0201 \\
(0.76)\end{array}$ & $\begin{array}{r}0.00233 \\
(0.09)\end{array}$ \\
\hline Crime, theft & $\begin{array}{r}-0.0589^{*} \\
(-2.08)\end{array}$ & $\begin{array}{r}-0.0415 \\
(-1.41)\end{array}$ & $\begin{array}{r}-0.0658^{*} \\
(-2.32)\end{array}$ & $\begin{array}{r}-0.0457 \\
(-1.55)\end{array}$ \\
\hline Tax rates & $\begin{array}{r}-0.0548^{*} \\
(-2.32)\end{array}$ & $\begin{array}{r}-0.0367 \\
(-1.51)\end{array}$ & $\begin{array}{r}-0.0558^{*} \\
(-2.37)\end{array}$ & $\begin{array}{r}-0.0343 \\
(-1.42)\end{array}$ \\
\hline Tax administration & $\begin{array}{r}0.0286 \\
(1.02)\end{array}$ & $\begin{array}{r}0.0309 \\
(1.09)\end{array}$ & $\begin{array}{r}0.0281 \\
(1.01)\end{array}$ & $\begin{array}{r}0.0292 \\
(1.03)\end{array}$ \\
\hline Business licensing & $\begin{array}{r}-0.0309 \\
(-1.07)\end{array}$ & $\begin{array}{r}-0.0255 \\
(-0.87)\end{array}$ & $\begin{array}{r}-0.0338 \\
(-1.17)\end{array}$ & $\begin{array}{r}-0.0275 \\
(-0.94)\end{array}$ \\
\hline Political instability & $\begin{array}{r}-0.0279 \\
(-1.17)\end{array}$ & $\begin{array}{r}0.00897 \\
(0.32)\end{array}$ & $\begin{array}{r}-0.0266 \\
(-1.12)\end{array}$ & $\begin{array}{r}0.00656 \\
(0.24)\end{array}$ \\
\hline Corruption & $\begin{array}{r}-0.00561 \\
(-0.25)\end{array}$ & $\begin{array}{r}-0.0228 \\
(-0.96)\end{array}$ & $\begin{array}{r}-0.00648 \\
(-0.28)\end{array}$ & $\begin{array}{r}-0.0229 \\
(-0.96)\end{array}$ \\
\hline Courts & $\begin{array}{r}0.100^{* * *} \\
(3.35)\end{array}$ & $\begin{array}{r}0.0935^{* *} \\
(3.01)\end{array}$ & $\begin{array}{r}0.110^{* * *} \\
(3.67)\end{array}$ & $\begin{array}{r}0.0989^{* *} \\
(3.20)\end{array}$ \\
\hline Access to finance & $\begin{array}{r}0.194^{* * *} \\
(8.70)\end{array}$ & $\begin{array}{r}0.204^{* * * *} \\
(8.64)\end{array}$ & $\begin{array}{r}0.174^{* * *} \\
(7.68)\end{array}$ & $\begin{array}{r}0.186^{* * *} \\
(7.88)\end{array}$ \\
\hline Labor regulations & $\begin{array}{r}0.0127 \\
(0.41)\end{array}$ & $\begin{array}{r}0.0180 \\
(0.56)\end{array}$ & $\begin{array}{r}0.0244 \\
(0.78)\end{array}$ & $\begin{array}{r}0.0277 \\
(0.86)\end{array}$ \\
\hline Inadequate education & $\begin{array}{r}0.0404 \\
(1.50)\end{array}$ & $\begin{array}{r}0.0528 \\
(1.89)\end{array}$ & $\begin{array}{r}0.0494 \\
(1.83)\end{array}$ & $\begin{array}{r}0.0607^{*} \\
(2.17)\end{array}$ \\
\hline $\log ($ No. of employees $)$ & & & $\begin{array}{r}-0.0435^{* * *} \\
(-6.29)\end{array}$ & $\begin{array}{r}-0.0553^{* * *} \\
(-7.57)\end{array}$ \\
\hline Constant & $\begin{array}{r}-0.201^{* * *} \\
(-14.53)\end{array}$ & $\begin{array}{r}-0.0273 \\
(-0.13)\end{array}$ & $\begin{array}{r}-0.0331 \\
(-1.11)\end{array}$ & $\begin{array}{r}-0.109 \\
(-0.50)\end{array}$ \\
\hline Country dummies & NO & YES & NO & YES \\
\hline $\begin{array}{l}N \\
R^{2}\end{array}$ & $\begin{array}{l}21535 \\
0.006\end{array}$ & $\begin{array}{l}21535 \\
0.014\end{array}$ & $\begin{array}{l}21527 \\
0.008\end{array}$ & $\begin{array}{r}21527 \\
0.017\end{array}$ \\
\hline
\end{tabular}

Notes: t-statistics in parentheses. ${ }^{*} p<0.10,{ }^{* *} p<0.05,{ }^{* *} p<0.01$. Heteroscedasticity-consistent standard errors.

Source: Author's calculation from the World Bank Enterprise Survey data. 


\section{Firm-Level Results for Asian Countries}

We now compare the results for the sample of 62 countries with those from Asian countries. There are 13 Asian countries in our sample (see Table 1). Table 9 presents the percentage of firms in all available countries that declare each obstacle as major or very severe. Comparing this with Table 2, we can observe that, in general, there are no major differences in terms of the relative incidence of obstacles. Generally, the incidence of obstacles is lower than in the complete sample. Crime and theft, access to finance, informal sector, and corruption all appear to be markedly lower for Asian countries. However, this hides important differences between countries. For instance, for poorer countries such as Pakistan and Bangladesh, infrastructure obstacles like electricity appear to be the most frequent declared obstacles. Corruption is very important for India and the Philippines, and political instability for Nepal, Mongolia, Bangladesh, Pakistan, and Myanmar.

Table 9: Prevalence of Obstacles in Asian Countries

\begin{tabular}{lc}
\hline Variable & $\begin{array}{c}\text { \% of Firms Declaring } \\
\text { Obstacle }\end{array}$ \\
\hline Electricity & 0.353 \\
Transportation & 0.138 \\
Customs and trade regulations & 0.133 \\
Informal sector & 0.174 \\
Access to land & 0.192 \\
Crime, theft & 0.096 \\
Tax rates & 0.242 \\
Tax administration & 0.153 \\
Business licensing & 0.111 \\
Political instability & 0.266 \\
Corruption & 0.256 \\
Courts & 0.108 \\
Access to finance & 0.198 \\
Labor regulations & 0.081 \\
Inadequate education & 0.167 \\
\hline
\end{tabular}

Source: Author's calculation from the World Bank Enterprise Survey data.

Figures 2 to 5 present only the regression coefficients and their $95 \%$ confidence intervals. The blue dots correspond to the full sample, and the red dots to the Asian countries. The figures allow us to visualize differences between Asia and the rest of the sample. For brevity, we only present results for the regression coefficients for $\tau_{y}$ (Figures 2 and 3 ) and $\tau_{k}$ (Figures 4 and 5). The first and second sets of results for each dependent variable present the outcomes without and with country dummies, respectively. All the coefficients come from regressions using size as a control. 

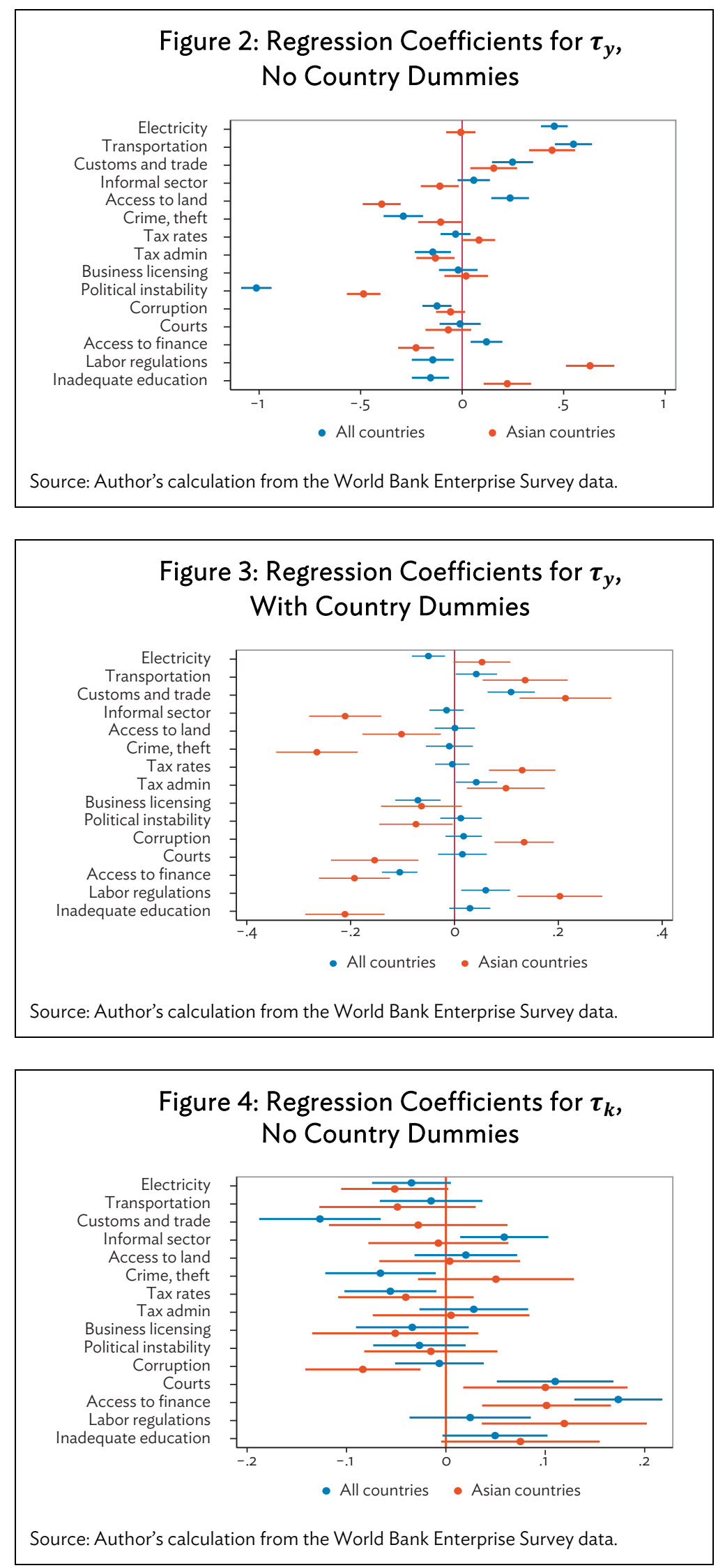


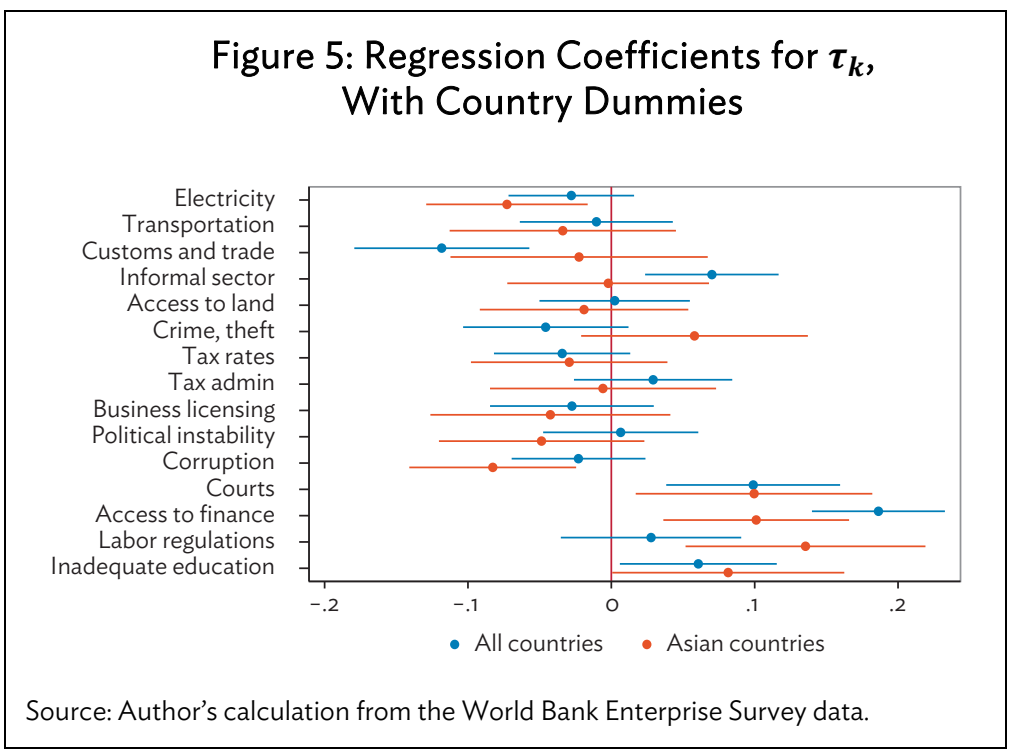

The results for $\tau_{y}$ highlight several key aspects. First, political instability appears to be much less important for Asian countries, especially when we do not control for country effects. On the contrary, crime and theft has a larger impact on Asian countries and acts as a size tax. Secondly, labor market obstacles appear to be much more important for Asian countries. When we control for country effects, inadequate education acts as a size tax for firms. Labor regulations, however, appear to act as a distortion that increases size relative to optimal for the cross-country variation. Finally, access to land appears to be quantitatively more important and acts as a tax reducing the size of firms relative to their optimal size.

The results for the factor market distortion do not reveal any sharp difference between Asia and the whole sample. Access to finance appears to have a smaller effect in Asian countries and, again, labor market obstacles (especially regulations) are quantitatively more important and act as a tax on capital (a subsidy for labor). Corruption is also more significant in both specifications, acting as a subsidy to capital.

\section{E. Splitting Countries by Levels of Development}

Finally, we split the sample by level of economic development. We rank countries by per capita income levels in 2010 using their per capita gross domestic product converted to international dollars using purchasing power parity rates from the World Bank International Comparison Program. We then split the sample into the $50 \%$ richest and poorest and perform the same regressions as before. Although it is a rough split, this can reveal differences in the main drivers of distortions at different stages of economic development. 

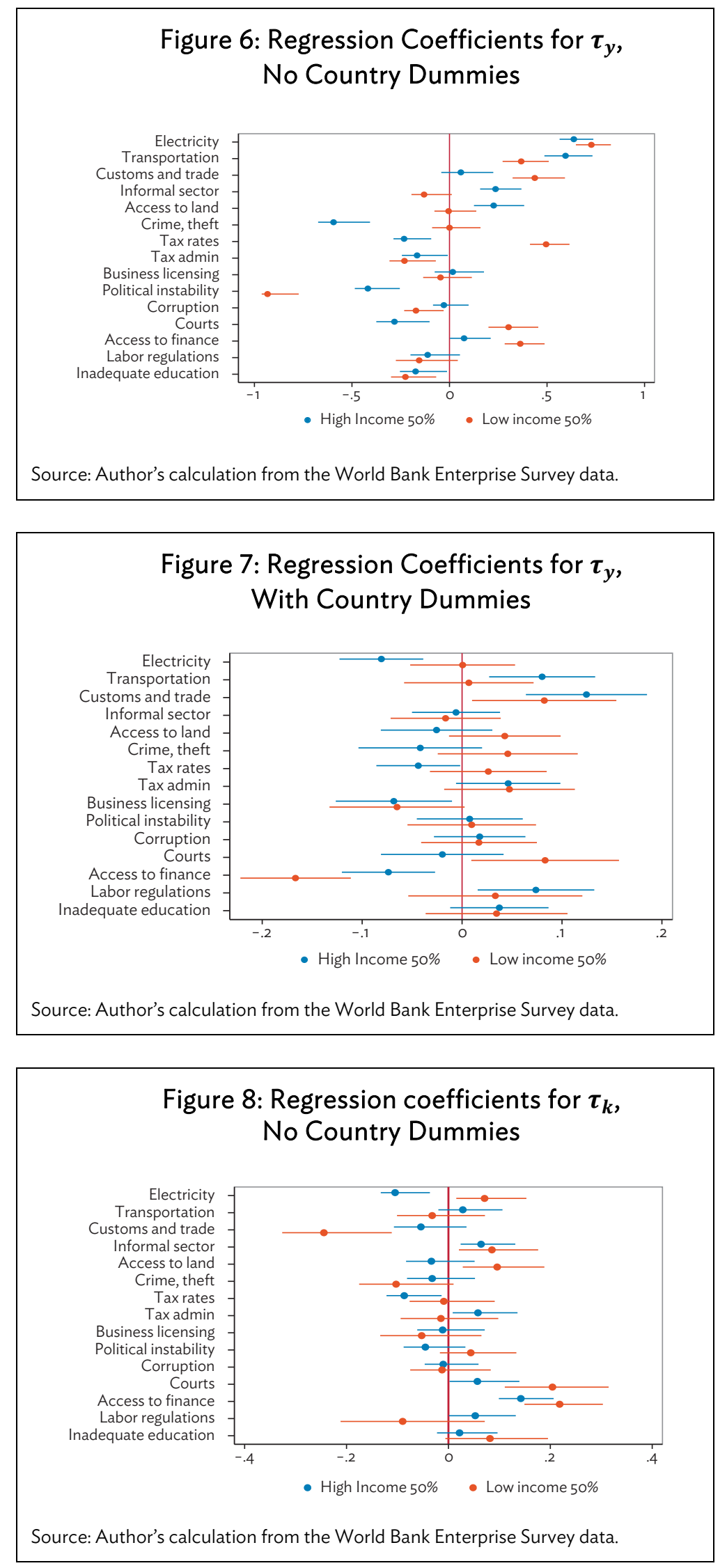


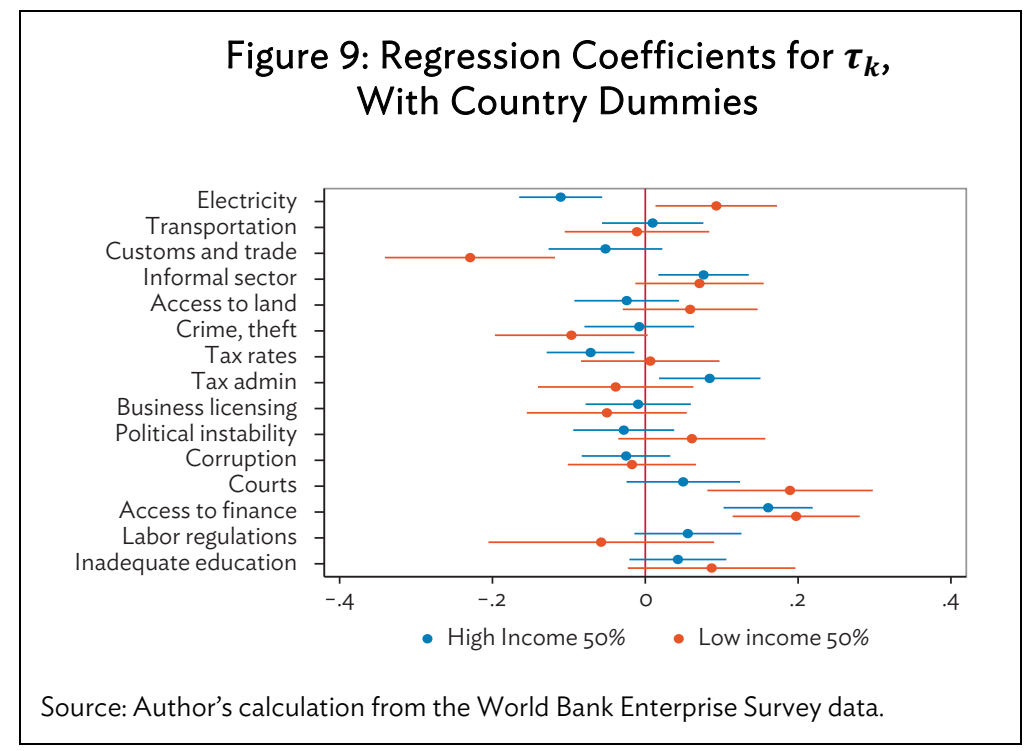

The results are displayed in Figures 6-9. Several relevant differences are worth highlighting. When we do not control for country dummies, political instability, customs and trade, and access to finance all appear more significant for the size distortions in poor countries. Controlling for them, only courts and access to finance appear to be more significant for poorer countries, whereas transportation is less so. Regarding the factor market distortion, only courts and customs and trade and, to a smaller degree, access to finance appear more important for poor countries.

\section{CONCLUSIONS}

One of the key determinants of potential growth are productivity gains. Recent literature has emphasized the role of misallocation in explaining TFP differences between countries. The existence of distortions in goods and factor markets prevents the efficient allocation of factors of production across firms, leading to aggregate productivity loses. Thus, potential productivity gains can be achieved by removing these distortions allowing for a more efficient allocation at the firm level. In this paper, we study what the main institutional obstacles that drive these distortions are. We use a firm-level database for 62 emerging economies and around 21,000 firms to analyze which of the institutional obstacles declared by firms appear to predict measures of size and factor market distortions.

Our results find a large degree of misallocation revealed by the dispersion in idiosyncratic distortions to both size and factor markets. Several of the obstacles that firms declare to affect their operations are highly correlated with measures of distortions derived from a theoretical framework. They reveal the importance of trade regulations, the functioning of courts, and access to finance as key determinants of misallocation within countries. Political instability, labor regulations, and access to infrastructure, appear as relevant obstacles explaining differences in misallocation between countries. For Asian countries, crime and theft, corruption, labor market regulations, and access to finance appear to be quantitatively more important. For the poorer countries in the sample, the functioning of courts, customs and trade regulations, and access to finance are more important than for the richer countries in the sample. 
The results provide a framework to understand the type of institutional inefficiencies whose correction can trigger important productivity gains leading to increases in potential growth. They also highlight the importance of understanding productivity building from a micro perspective. For this, developing and maintaining firm-level datasets for emerging economies is an important policy task as it allows for closely monitoring the effects of policy reforms on productivity growth through their impact on firm dynamics. 


\section{REFERENCES}

Baily, M., C. Hulten, and D. Campbell. 1992. Productivity Dynamics in Manufacturing Plants. Brooking Papers on Economic Activity: Microeconomics. pp. 187-267.

Banerjee, A., and E. Duflo. 2005. Growth Theory through the Lens of Development Economics. Handbook of Economic Growth. Vol 1A, Chapter 7. North-Holland.

Banerjee, A., and B. Moll. 2010. Why Does Misallocation Persist? American Economic Journal: Macroeconomics. 2 (1). pp. 189-206.

Bartelsman, E., J. Haltiwanger, and S. Scarpetta. 2013. Cross-Country Differences in Productivity: The Role of Allocation and Selection. American Economic Review. 103 (1). pp. 305-34.

Buera, F., J. Kaboski, and Y. Shin. 2011. Finance and Development: A Tale of Two Sectors. American Economic Review. 101 (5). pp. 1964-2002.

Caselli, F. 2005. Accounting for Cross-Country Income Differences. In P. Aghion and S. Durlauf, eds. Handbook of Economic Growth. North-Holland.

Epifani, P., and G. Gancia. 2011. Trade, Markup Heterogeneity and Misallocations. Journal of International Economics. 83 (1). pp. 1-13.

Foster, L., J. Haltiwanger, and C. Syverson. 2008. Reallocation, Firm Turnover, and Efficiency: Selection on Productivity or Profitability? American Economic Review. 98 (1). pp. 394-425.

Guner, N., G. Ventura, and Y. Xu. 2008. Macroeconomic Implications of Size-Dependent Policies. Review of Economic Dynamics. 11 (4). pp. 721-44.

Ha, D. T. T., and K. Kiyota. 2015. Misallocation, Productivity, and Trade Liberalization: The Case of Vietnamese Manufacturing. Keio University. Mimeo.

Hopenhayn, H. 1992. Entry, Exit, and Firm Dynamics in Long Run Equilibrium. Econometrica. 60 (5). pp. 1127-50.

Hopenhayn, H., and R. Rogerson. 1993. Job Turnover and Policy Evaluation: A General Equilibrium Analysis. Journal of Political Economy. 101 (5). pp. 915-38.

Hsieh, C., and P. Klenow. 2009. Misallocation and Manufacturing TFP in China* and India. Quarterly Journal of Economics. 124 (4). pp. 1403-48.

2012. The Life-Cycle of Plants in India and Mexico. NBER Working Paper 18133. National Bureau of Economic Research.

Jones, C. 2011. Misallocation, Economic Growth, and Input-Output Economics. NBER Working Paper 16742. National Bureau of Economic Research.

* ADB recognizes "China” as the People's Republic of China. 
Kalemli-Ozcan, S., and B. Sorensen. 2012. Misallocation, Property Rights, and Access to Finance: Evidence from Within and Across Africa. NBER Working Paper 18030. National Bureau of Economic Research.

León-Ledesma, M. A., P. McAdam, and A. Willman. 2010. Identifying the Elasticity of Substitution with Biased Technical Change. American Economic Review. 100 (4). pp. 1330-57.

2015. Production Technology Estimates and Balanced Growth. Oxford Bulletin of Economics and Statistics. 77 (1). pp. 40-65.

Melitz, M., and S. Polanec. Forthcoming. Dynamic Olley-Pakes Decomposition with Entry and Exit. RAND Journal of Economics.

Midrigan, V., and D. Yi Xu. 2014. Finance and Misallocation: Evidence from Plant-Level Data. American Economic Review. 104 (2). pp. 422-58.

Moll, B. 2014. Productivity Losses from Financial Frictions: Can Self Financing Undo Capital Misallocation? American Economic Review. 104 (10). pp. 3186-221.

Olley, S., and A. Pakes. 1996. The Dynamics of Productivity in the Telecommunications Industry. Econometrica. 64 (6). pp. 1263-98.

Restuccia, D. 2013. Factor Misallocation and Development. The New Palgrave Dictionary of Economics. Palgrave Macmillan.

Restuccia, D., and R. Rogerson. 2008. Policy Distortions and Aggregate Productivity with Heterogenous Establishments. Review of Economic Dynamics. 11 (4). pp. 707-20.

2013. Misallocation and Productivity. Review of Economic Dynamics. 16 (1). pp. 1-10.

Udry, C. 2011. Misallocation, Growth and Financial Market Imperfections. Yale University. Manuscript. 


\section{Potential Growth, Misallocation, and Institutional Obstacles: Firm-Level Evidence}

A key determinant of total factor productivity is misallocation: aggregate productivity losses arising from microeconomic distortions that prevent an efficient allocation of factors of production between firms. Reallocation of factors due to the elimination of distortions can increase potential growth for sustained periods of time. We use firm-level data for 62 developing countries to analyze the most important institutional obstacles driving misallocation. Our results highlight the importance of trade regulations, functioning of courts, and access to finance as key determinants of misallocation within countries. Political instability, labor regulations, and access to infrastructure, appear as relevant obstacles explaining misallocation between countries.

\section{About the Asian Development Bank}

ADB's vision is an Asia and Pacific region free of poverty. Its mission is to help its developing member countries reduce poverty and improve the quality of life of their people. Despite the region's many successes, it remains home to the majority of the world's poor. ADB is committed to reducing poverty through inclusive economic growth, environmentally sustainable growth, and regional integration.

Based in Manila, ADB is owned by 67 members, including 48 from the region. Its main instruments for helping its developing member countries are policy dialogue, loans, equity investments, guarantees, grants, and technical assistance. 